\title{
An Antitrust Rule for Software Integration
}

\section{J. Gregory Sidak ${ }^{\dagger}$}

What is the proper legal standard for product integration involving software? Because software is subject to low marginal costs, network effects, and rapid technological innovation, the Supreme Court's existing antitrust rules on tying arrangements, which evolved from industries not possessing such characteristics, are inappropriate. In this Article, I ask why firms integrate software products. Next, I review the Supreme Court's tying decisions in Jefferson Parish and Eastman Kodak. I propose an approach to judging the lawfulness of product integration in technologically dynamic markets that supplements the Supreme Court's current standard with four additional steps in cases of tying of computer software. Thereafter, I examine the D.C. Circuit's approach to software integration, which arose from that court's 1998 interpretation, in Microsoft II, of an antitrust consent decree between the U.S. Department of Justice and Microsoft Corporation. I argue that the D.C. Circuit's rule has general applicability and should be recognized as the appropriate standard for software integration under antitrust law. I show how my approach imparts greater clarity to the D.C. Circuit's rule. I examine the competing product integration rule proposed in 2000 by Professor Lawrence Lessig as amicus curiae in the government's subsequent antitrust case against Microsoft, concerning the integration of Internet Explorer and Windows 98. My approach enables Professor Lessig's analysis to be reconciled with the D.C. Circuit's rule, but Professor Lessig's rule, on its own, would contain serious shortcomings. Thereafter, I evaluate Judge Thomas Penfield Jackson's April 2000 findings of law on the integration of Internet Explorer and Windows 98. I conclude that Judge Jackson's approach, in contrast to the D.C. Circuit's rule as refined by my approach, would harm consumers in the technologically dynamic market for computer software.

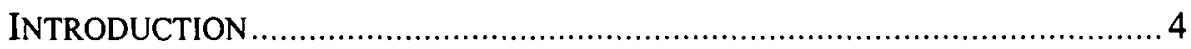

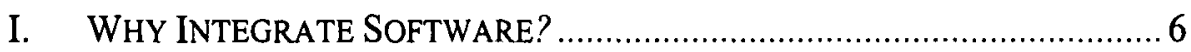

A. Chicago School Explanations for the Efficiency of Product

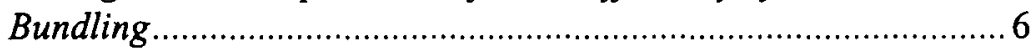

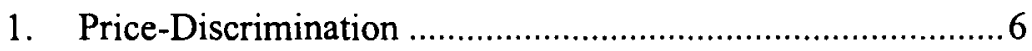

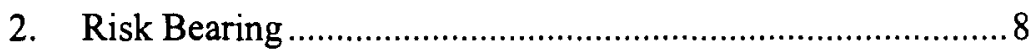

$\dagger \quad$ F. K. Weyerhaeuser Fellow in Law and Economics, American Enterprise Institute for Public Policy Research. The author has been a consultant to the Microsoft Corporation. The views expressed herein are solely the author's. 


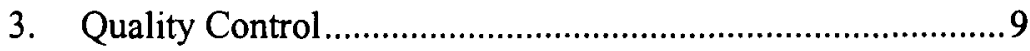

B. Post-Chicago Anticompetitive Explanations for the Bundling of Software Products ............................................................... 10

1. Monopoly Leveraging into the Browser Market .................. 10

2. Preservation of Monopoly in the Operating System Market 11

C. Post-Chicago Procompetitive Explanations for the Bundling of Software Products............................................................... 15

1. Responding to Diversity of Buyer Valuations for Software. 16

2. Stimulating Demand for Complementary Products and Features....................................................................... 17

3. Generating Revenue from Ancillary Services ...................... 18

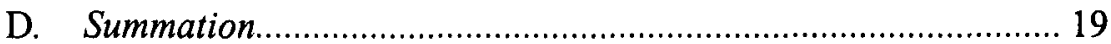

II. THE SUPREME COURT'S JURISPRUDENCE ON TYING AFTER JEFFERSON PARISH AND EASTMAN KODAK ……............................... 20

A. The Jefferson Parish Decision …….......................................... 21

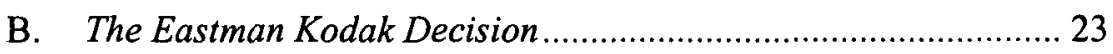

III. ANALYZING PRODUCT INTEGRATION IN TECHNOLOGICALLY

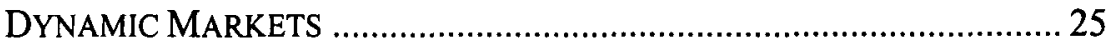

A. The Uninformative Preoccupation with "Separate Products".... 26

B. When Is a Market Technologically Dynamic? ............................ 26

C. Four Proposed Steps for Evaluating Product Integration in Technologically Dynamic Markets

1. Step One: Is the Market Technologically Mature or Technologically Dynamic?

2. Step Two: Is It Plausible that Consumers Will Benefit from Subadditive Costs or Superadditive Demand Resulting from Product Integration?

3. Step Three: Is It Probable That Integration Will Preserve a Monopoly over the Tying Product by Substantially Reducing Competition from the Tied Product?

4. Step Four: Will the Reduction, If Any, in Competition Cause Consumer Welfare Losses That Exceed the Consumer Welfare Gains from Subadditive Costs or Superadditive Demand? 
An Antitrust Rule for Software Integration

D. Summation.......................................................................... 33

IV. THE D.C. CIRCUIT'S SOFTWARE INTEGRATION RULE ANNOUNCED

IN MICROSOFT II .................................................................... 34

A. The Anti-Tying Provisions of the 1994 Microsoft Consent

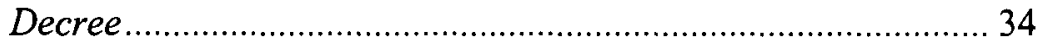

B. May the Interpretation of an Antitrust Consent Decree Compromise the Goal of Consumer-Welfare Maximization That Is the Foundation of the Antitrust Laws? ................................. 38

C. Deriving the "Plausible Consumer Benefit" Rule from First Principles of Antitrust Law ..................................................... 41

D. Application of the Product Integration Rule ............................ 44

E. Judge Wald's Balancing Test................................................. 46

F. Summation.................................................................... 48

V. JUDGE JACKSON'S 1999 FINDINGS OF FACT CONCERNING

MICROSOFT'S INTEGRATION OF INTERNET EXPLORER AND WINDOWS 98

A. Middleware Threats to Microsoft's Operating System Monopoly

B. Microsoft's Response to the Browser Threat ............................ 50

VI. PROFESSOR LESSIG'S PROPOSED SOFTWARE INTEGRATION RULE ...... 54

A. Professor Lessig's Application of Microsoft II and Jefferson Parish to the 1999 Findings of Fact in the Microsoft Case......... 56

B. Professor Lessig's Proposed Rule ........................................ 57

C. The Limitations of Professor Lessig's Rule ............................. 59

1. Integrated Functionalities and Strategic Code Writing ........59

2. The Tied Product as a Partial Substitute for the Tying

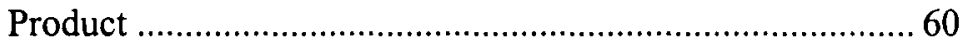

a. Taking Partial Substitutes Seriously...............................60

b. Partial Substitutes as a Metaphor..................................63

3. Substitutability and Market Definition: Intel-compatible PC Operating Systems versus Applications Platforms........ 64

4. Real Options and the Oddity of Disabling as an Antidote to Tying 
5. The Revelation of Consumer Demand: Professor Lessig's Price Theory or Professor Knight's?.

6. The Comparative Inefficiency of Consumer Bundling of Software

7. Preordaining the Answer: Equating the Separateness of Products with an Anticompetitive Effect of Integration

8. Does the Lawfulness of Product Integration under Professor Lessig's Rule Ultimately Collapse into an Analysis of Predation?...................................................... 70

9. The Limits of Complex Legal Rules ...................................... 70

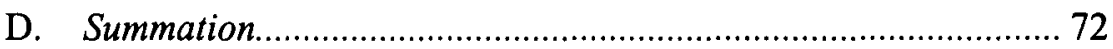

VII. JUDGE JACKSON'S SOFTWARE INTEGRATION RULE ............................. 73

A. Judge Jackson's Deference to Microsoft II in His 1998

Summary Judgment Motion ...................................................... 74

B. Judge Jackson's 2000 Findings of Law ..................................... 74

C. The Rejection of Microsoft II in Favor of Jefferson Parish and

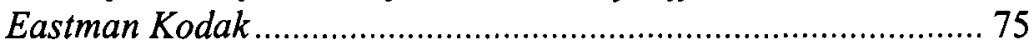

D. The Application of Jefferson Parish and Eastman Kodak to the 1999 Findings of Fact in the Government's Microsoft Case...... 78

E. The Deficiency of Judge Jackson's Rule .................................... 80

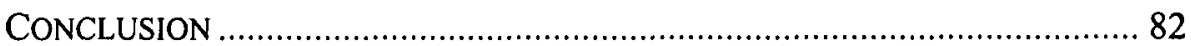

\section{INTRODUCTION}

One of the great challenges in antitrust law today is articulating the proper rule by which to judge the lawfulness of product integration involving software. Unlike the smokestack industries that have produced most of the antitrust jurisprudence on tie-ins, software is subject to low marginal costs, network effects, and rapid technological innovation. The need for a properly tailored rule for product integration for software is manifested in the growth of the Internet and electronic commerce, which in turn is accelerating the convergence of the information-based industries that heretofore had distinct identities in the minds of consumers, managers, and government officials. Today, computing, entertainment, financial services, retailing, and telecommunications- to name only the most obvious-are industries whose output can be aggregated on a common electronic platform for delivery to 
consumers. In the "New Economy," will such aggregations of software functionalities be praised as beneficial to consumers, or will they be condemned as unlawful tie-ins?

In Part II, I examine the economic theories of why firms integrate software products. In Part III, I review the Supreme Court's most recent jurisprudence on tying-the 1984 decision in Jefferson Parish Hospital District No. 2 v. Hyde 1 and the 1992 decision in Eastman Kodak Co. v. Image Technical Services, Inc. ${ }^{2}$-and consider why those decisions are inadequate to address tying in technologically dynamic markets. In Part IV, I propose an approach to the law of tying arrangements, the overarching purpose of which is to instill within tying doctrine a filter that discriminates between technologically mature and technologically dynamic product markets. In Part V, I explain why my proposed rule is consistent with the leading case on product integration for software, the 1998 decision by the U.S. Court of Appeals for the District of Columbia Circuit in United States $v$. Microsoft Corp. (Microsoft II). ${ }^{3}$

In Part VI, I shift to the 1999 antitrust trial of Microsoft, which dealt with the company's practices concerning the design and marketing of the Windows 98 operating system and the Internet Explorer Web browser. I briefly summarize the portions of Judge Thomas Penfield Jackson's findings of fact that are relevant to the question of whether Microsoft engaged in unlawful tying of Internet Explorer to Windows 98 in violation of $\S 1$ of the Sherman Act. An understanding of these factual findings is essential to understanding how different outcomes would result from different possible product integration rules.

In Part VII, I consider, as an alternative to the rule of Microsoft II and to my proposed approach, the product integration rule that Professor Lawrence Lessig, then of Harvard Law School, advocated in the amicus brief that he filed in the government's current Microsoft case at the request of Judge Jackson after the judge issued findings of fact. ${ }^{4}$ Professor Lessig's analysis helps to clarify the D.C. Circuit's product integration rule in Microsoft II, and it is potentially reconcilable with the approach that I propose. However, Professor Lessig's rule does not provide a basis for departing from an application of Microsoft II in the current Microsoft case or in general.

In Part VIII, I analyze, as a second alternative to the rule of Microsoft II, Judge Jackson's April 2000 conclusion of law in the Microsoft case as it 
pertains to the integration of Windows 98 and Internet Explorer. 5 Judge Jackson declined to apply Microsoft II and, indeed, said that it is inconsistent with Supreme Court precedent. To a lesser extent, he relied on elements of the reasoning underlying Professor Lessig's proposed rule. I explain why Judge Jackson's rule would be less likely to maximize consumer welfare than the rule of Microsoft II, as refined by my proposed approach.

\section{Why Integrate Software?}

Some of the traditional economic explanations for product bundling more accurately fit smokestack industries than software. The network effects, low marginal costs, and rapid technological change in software create rationales for product integration that are both less familiar and more subtle than the bundling arguments that courts have previously encountered. It is important to establish the range of economic benefits to consumers that may flow from the integration of software, because those consumer-welfare effects will, of course, be the criterion by which courts select the optimal antitrust rule in this area. In the remainder of Part II, I first review the traditional Chicago School rationales for the efficiency of product bundling. I then examine the "post-Chicago" procompetitive explanations for bundling software products. Finally, I address the post-Chicago theories of anticompetitive bundling and ask whether they apply to the software industry.

\section{A. Chicago School Explanations for the Efficiency of Product Bundling}

The Chicago School of antitrust analysis produced several familiar economic rationales for why product integration might be procompetitive or efficiency-enhancing. ${ }^{6}$ I consider the major rationales and their possible relevance to the Microsoft case.

\section{Price-Discrimination}

The original motivation for product bundling offered by Chicago School economists was price-discrimination. ${ }^{7}$ The Court's modern jurisprudence on

5 United States v. Microsoft Corp., 87 F. Supp. 2d 30 (D.D.C. 2000) [hereinafter Microsoft Findings of Law].

6 Portions of the following discussion draw from J. Gregory Sidak, Debunking Predatory Innovation, 83 COLUM. L. REV. 1121 (1983). REV. 152.

7 George J. Stigler, United States v. Loew's Inc.: A Note on Block Booking, 1963 SUP. CT. 
tying, such as Jefferson Parish, ${ }^{8}$ recognizes that tie-ins between goods used in variable proportions may be motivated by the desire to price-discriminate. ${ }^{9} \mathrm{~A}$ tie-in can be used to price-discriminate if (1) the tying firm possesses market power in the tying product market, (2) the tied and tying products (a) are used in variable proportions and (b) are complementary, and (3) the willingness of consumers to pay for a system depends, at least to some extent, on the number of times they intend to use it. The use of tying to effect price-discrimination is likely to enhance social welfare because it tends to induce the monopolist to increase output to the socially optimal level, which would obtain under competitive conditions, thus eliminating the deadweight loss of a single-price monopoly strategy. A firm that successfully pricediscriminates manages to make each consumer pay the most that she is willing to spend for a given product-that is, her "reservation price."10

Many of the litigated allegations of technological tying and predatory innovation in the late 1970 s and early 1980 s involved tie-ins of inputs used in variable proportions." One of the earliest reported cases, Automatic Radio Manufacturing Co. v. Ford Motor Co.,12 involved a fixed-proportion technological tie-in that seems quaint when compared with the complexity of the technological tying claims that have been alleged in recent years in the computer software and hardware industries. Ford changed its dashboard

8466 U.S. 2, 14-15 (1984).

9 E.g., WaRD S. BOWMAN, JR., PATENT AND ANTitrust LaW: A Legal AND ECONOMiC APPRAISAL 76-88 (1973); Ward S. Bowman, Jr., Tying Arrangements and the Leverage Problem, 67 YALE L.J. 19, 23-24 (1957); Aaron Director \& Edward H. Levi, Law and the Future: Trade Regulation, 51 Nw. U. L. REV. 281, 291-92 (1956). For a later explication and application of the price-discrimination theory of tying, see William F. Baxter, Legal Restrictions on Exploitation of the Patent Monopoly: An Economic Analysis, 76 Y ALE L.J. 267 (1966).

10 E.g., HAL R. VARIAN, MiCROECONOMIC ANALYSIS 153, 416 (3d ed. 1992). Later proponents of the price-discrimination view recognized that bundling is advantageous when valuations of the goods are negatively correlated. E.g., Richard Schmalensee, Commodity Bundling by Single-Product Monopolies, 25 J.L. \& ECON. 67 (1982). When a firm must charge one price to customers, variability in customer valuations undermines that firm's ability to capture consumer surplus. To the extent that bundling reduces the variability of valuations, it can be used to capture a greater share of consumer surplus and thus increase profits. Under this assumption, bundling would have its greatest advantage when the valuations of the two products are perfectly negatively correlated.

11 In the late 1970s and early 1980s, the Kodak litigation and IBM peripheral-device litigation involved technological tie-ins of variable proportions. Foremost Pro Color, Inc. v. Eastman Kodak Co., 703 F.2d 534 (9th Cir. 1983); California Computer Prods., Inc. v. Int'l Bus. Machs. Corp., 613 F.2d 727 (9th Cir. 1979); Berkey Photo, Inc. v. Eastman Kodak Co., 603 F.2d 263 (2d Cir. 1979); Transamerica Computer Co. v. Int'l Bus. Machs. Corp., 481 F. Supp. 965 (N.D. Cal. 1979), aff'd and modified on other grounds, 698 F.2d 1377 (9th Cir. 1983); ILC Peripherals Leasing Corp. v. Int'l Bus. Machs. Corp., 458 F. Supp. 423 (N.D. Cal. 1978), aff'd sub nom. Memorex Corp. v. Int'l Bus. Machs. Corp., 636 F.2d 1188 (9th Cir. 1980) (per curiam); Telex Corp. v. Int'l Bus. Machs. Corp., 367 F. Supp. 258 (N.D. Okla. 1973), rev'd on other grounds, 510 F.2d 894 (10th Cir. 1975). In all of these cases the plaintiff was a competitor. See also Rapid Print, Inc. v. Minn. Mining \& Mfg. Co., 1980-81 Trade Cas. (CCH) ๆ 63,787 (D. Mass. Jan. 30, 1981) (granting defendant summary judgment in a suit by a consumer under $\S 2$ claiming that the defendant had extracted excessive profits by designing a technological tie-in).

12272 F. Supp. 744 (D. Mass. 1967), aff'd, 390 F.2d 113 (1st Cir. 1969). 
design so that a radio could not be installed without the dealer first purchasing from Ford a dashboard plate with holes to accommodate the radio. Even this case may be viewed as involving inputs used in variable proportions, because a car may either have a radio or not have one (unlike, say, a transmission that is necessary for the car to function).

For at least three reasons, the traditional Chicago School analysis of tying as price-discrimination does not shed light on Microsoft's integration of Internet Explorer into the Windows operating system. First, as Dean Richard Schmalensee noted in his 1999 testimony in the Microsoft case, in the traditional tying case "there is a significant incremental cost of adding the tied product to the tying product, and these costs are not reduced substantially as a result of bundling." 13 In the case of software, however, the incremental cost of product bundling is low. That low incremental cost of adding features or functionalities can make possible consumer-welfareenhancing strategies that are not possible for a firm that faces relatively high incremental costs of product integration.

Second, the incremental price that Microsoft charged for the integration of Internet Explorer into Windows 98 was zero. Thus, as Dean Schmalensee has noted, one cannot condemn Microsoft's bundling of Internet Explorer and Windows 98 on the belief that it will enable the producer to charge supracompetitive prices for the tied product. 14

Third, such bundling does not fit the traditional Chicago School explanation that a tying arrangement facilitates price-discrimination by metering consumer demand. The consumer with a low price elasticity of demand does not purchase multiple Internet Explorer Web browsers. Nor is her Web browser priced on the basis of her frequency or intensity of use.

\section{Risk Bearing}

A strategy of price-discrimination through product bundling may have desirable welfare effects other than the tendency to reduce deadweight loss by increasing output to the competitive level. Because of limited information and risk aversion, consumers might actually favor a pricing strategy for a new product system that would discriminate on the basis of intensity of use. For some products, especially brand new ones, a consumer will be uncertain how strongly she really demands the product, so that ex ante the producer cannot accurately ascertain the price elasticity of demand for the new system and thus

13 Direct Testimony of Professor Richard L. Schmalensee on behalf of Microsoft Corp., I 522 , United States v. Microsoft Corp., (No. 98-1233) (D.D.C. 1999) [hereinafter Schmalensee Direct Testimony].

$14 \quad$ Id. $ๆ 523$. 
would have trouble identifying a single profit-maximizing price.15 This is especially true for a product system that embodies nonobvious or nonintuitive information: The consumer can only fully evaluate the product's utility to her ex post by actually using the system. This problem is merely another example of Kenneth Arrow's general insight that "there is a fundamental paradox in the determination of demand for information; its value for the purchaser is not known until he has the information, but then he has in effect acquired it without cost."16 Although it is plausible that a software manufacturer, such as Microsoft, seeks to reduce consumer risk of this sort and that product bundling may facilitate that objective (for reasons to be explained shortly), that result would not flow from a strategy of price-discrimination based on metering, as none appears to take place.

\section{Quality Control}

A tie-in also can be used to ensure proper performance of a product system, and the usefulness of this quality-control function, which is intended to preclude the consumer's use of the possibly inferior or incompatible components of a rival producer, does not depend on whether the tie-in is of fixed or variable proportion. 17 Courts have long recognized the protection of product quality to be a limited affirmative defense to the per se rule against contractual tie-ins. In United States v. Jerrold Electronics Corp., the court held that service contracts tied to a new antenna system were lawful during the period of the product's "inception," but that such contracts violated $\S 1$ of the Sherman Act and $\S 3$ of the Clayton Act after circumstances changed and the quality-control need for compulsory service contracts disappeared.18

This quality-control function is important when the consumer has a limited understanding of how the system works and thus might erroneously blame the producer of the system for a malfunction caused by an inferior or incompatible component manufactured by a competitor, who will consequently escape the full cost of consumer dissatisfaction and hence the full retribution of the marketplace. In a case involving the tying of automobile parts, one court observed:

Although there have been no examples presented by either side of specific incidents of engine failure resulting from the plaintiff's

15 See, e.g., 466 U.S. at 27-28.

16 KENNETH J. ARROW, ESSAYS IN THE THEORY OF RISK-BEARING 152 (2d ed. 1974).

17 ROBERT H. BORK, THE ANTITRUST PARADOX: A POLICY AT WAR WITH ITSELF 379-81 (1993); Tyler Baker, The Supreme Court and the Per Se Tying Rule: Cutting the Gordian Knot, 66 VA. L. REV. 1235, $1257-58,1277-78(1980)$.

18187 F. Supp. 545, 560-61 (E.D. Pa. 1960), aff d per curiam, 365 U.S. 567 (1961). 
[compatible] instruments malfunctioning, there is ample indication that if and when this may occur, the delineation of responsibility between the plaintiff and defendant regarding who will ultimately bear the liability is far from clear, thus resulting either in customer dissatisfaction, or in the defendant assuming a disproportionate share of the liability, rather than jeopardize its consumer goodwill. ${ }^{19}$

If the courts are willing to acknowledge the possible value of product bundling when the products are as straightforward as engines and instruments, then this economic rationale in defense of tie-ins should hold with even greater force when the products are software.

\section{B. Post-Chicago Anticompetitive Explanations for the Bundling of Software Products}

Several anticompetitive theories developed by post-Chicago scholars could potentially explain the bundling of software. In the following section, I review these theories and discuss whether their underlying assumptions are plausible in the context of software integration.

\section{Monopoly Leveraging into the Browser Market}

The idea that bundling could extend market power into a second market was largely discredited by the Chicago School. ${ }^{20}$ In particular, a firm with a monopoly in good $A$ gains no advantage by selling $A$ only as part of a bundle with a competitively supplied good $B$. Because $B$ is freely available at its marginal cost (as a result of perfect competition), a consumer who buys the bundle would also be willing to buy $A$ alone at the same profit margin for the monopolist. The idea of monopoly leveraging and other anticompetitive rationales for bundling, however, have resurfaced in the economic literature in recent years. In particular, Professor Michael Whinston produced a model showing that the Chicago School critique of leveraging theory only applies when the tied market is perfectly competitive. ${ }^{21}$ In his model, tying commits the monopolist to being more aggressive than the entrant, and this commitment discourages entry. Professor Whinston shows that tying could be used to deter entry into, and thereby monopolize, the tied product market

19 Teflex Indus. Prods., Inc. v. Brunswick Corp., 293 F. Supp. 106, 110 (E.D. Pa. 1968).

20 For the classic critiques of the monopolist's incentive to exclude a competitor's product in a complementary market (and for the classic efficiency justifications for tying), see BORK, supra note 17; RICHARD A. POSNER, ANTITRUST LAW: AN ECONOMIC PERSPECTIVE (1976); and Director \& Levi, supra note 9.

21 Michael Whinston, Tying, Foreclosure, and Exclusion, 80 AM. ECON. REV. 837 (1990). 
if (1) the selling firm is a monopolist in the tying product market, (2) the tied product market has decreasing average costs over the relevant range of output, and (3) the tied and tying products are used in variable proportions.22 Whinston finds, however, that the predicted welfare effects of even that specialized case of tying are ambiguous. ${ }^{23}$

Other recent theoretical papers have examined how bundling can be used as a commitment device. One paper finds that bundling gives the monopolist a greater incentive to engage in cost-cutting research and development and thus helps to preserve and extend its advantageous position. ${ }^{24}$ Again, however, the predicted welfare effects of that theoretical result are ambiguous. In a different theoretical paper, Professor Barry Nalebuff has demonstrated that bundling reduces the entrant's potential profits while mitigating the incumbent's profit loss if entry occurs. ${ }^{25}$ Hence, bundling is credible even without any commitment device. Professor Nalebuff also shows that even if there are no cost savings or value-creating synergies, the incumbent firm still has an incentive to engage in bundling for its entry-deterrence effect. ${ }^{26} \mathrm{He}$ explains that software is a good candidate for bundling because the marginal costs of producing software are low-as marginal costs rise, bundling creates an inefficiency because some consumers are forced to buy the bundle even though they value the components at less than their production costs. ${ }^{27}$

\section{Preservation of Monopoly in the Operating System Market}

Professors Dennis Carlton and Michael Waldman have extended Whinston's work on the leverage theory of bundling to investigate how the tying of complementary products can be used to preserve a monopoly position in the market for one of the products. ${ }^{28}$ Under this scenario, a monopoly firm operates in its primary market and in a market for a complementary good, in which it competes with an alternative producer. The monopoly firm has an incentive to tie if there is a threat of entry by the

22 Id. at 854 n.24.

23 Id. at $855-56$.

24 Jay Pil Choi, Tying and Innovation: A Dynamic Analysis of Tying Arrangements, (1998) (Working Paper, on file with the Yale JouRnal on REgulation); see also Jay Pil Choi \& Christodoulos Stefanadis, Tying. Investment, and the Dynamic Leverage Theory, RAND J. ECON. (forthcoming).

25 Barry Nalebuff, Bundling as an Entry Barrier (1999) (Working Paper, on file with the YALE JOURNAL ON REGULATION)

26 Id. at 4

27 Id.

28 DenNis W. Carlton \& Michael Waldman, The Strategic Use of Tying to PRESERVE AND CREATE MARKET POWER IN EVOLVING INDUSTRIES (Nat'l Bureau of Econ. Research, Working Paper \#145) (1999) (on file with the YALE JOURNAL OF REGULATION). 
alternative producer into the primary market. Professors Carlton and Waldman use dynamic models that point to the monopolist's ability to deter entry of efficient firms into the monopolist's primary market and related markets. They find that tying will preserve monopoly power in the primary market whenever the alternative producer in the tied market faces entry costs, or the demand for the complementary good is characterized by network effects. With respect to policy implications, however, Professors Carlton and Waldman suggest that any efficiencies from tying should be weighed against potential consumer harm, and that "efficiencies achieved through physical integration ... should receive greater weight than efficiencies achieved through contract." 29

Much of the government's economic theory in the 1999 trial of Microsoft focused on an elaborate version of this theory of anticompetitive tying. ${ }^{30}$ This economic theory was first presented in detail in the pretrial declaration of Professor David Sibley on behalf of the government in May 1998. ${ }^{31}$ There, Professor Sibley proposed that Microsoft's actions to put in place contracting restrictions and to distribute the Internet Explorer (IE) browser tied to its Windows operating system (OS) for free were an attempt to preserve its OS monopoly. ${ }^{32}$ To support his argument, Professor Sibley pointed to the case of a monopoly with allegedly exclusionary practices in a complementary market that it serves, where the general conclusion has been that

if the price level in the complement's market is limited by competitive forces, then in the absence of efficiency justifications... the monopolist's control over the bottleneck input does not give it any profit incentive to restrict or exclude a competitor's product in the complement's market ... [because] . . . control over the bottleneck input allows the monopolist to extract value from consumers no matter whose version of the complementary good the consumer buys. ${ }^{33}$

Applied to the Microsoft case, Professor Sibley stated, the bottleneck input is Microsoft's operating system, while the complementary product is the browser. ${ }^{34} \mathrm{He}$ maintained that the threat to Microsoft's alleged OS monopoly arose because browsers expose their own application programming interfaces

\footnotetext{
$29 J d$. at 38.

30 One commentator has dubbed this strategy "defensive leveraging." Robin Cooper Feldman, Defensive Leveraging in Antitrust, 87 GEO. L.J. 2079, 2098-99 (1999).

31 Declaration of David S. Sibley 94 49, United States v. Microsoft Corp., 147 F.3d 935 (D.C. Cir. 1998) (No. 98-1233) [hereinafter Sibley Declaration].

$32 \mathrm{Id}$.

33 Id. $\uparrow 44$

34 Id.
} 
(APIs), a condition that enables browsers to serve as a software applications platform independent of the underlying OS; in turn, the existence of a competing platform would break down the so-called "applications barrier to entry" in the PC operating systems market. A new entrant in the OS market, Professor Sibley reasoned, "would not have to create an installed base of software applications complementary to its OS and comparable to Microsoft's in its size and use in order to succeed." 35 Instead, applications that were written to the browser platform would be accessible to a user employing any OS that supported that browser.

Today, profits from browsers are usually generated from Internetrelated businesses, such as referral fees from Internet access providers (IAPs) and advertising revenues. ${ }^{36}$ Professor Sibley proposed that Microsoft has "incurred an opportunity cost by foregoing the additional value it could have extracted from consumers"-or from original equipment manufacturers (OEMs), IAPs, and Internet content providers (ICPs)-that wanted to use Navigator. ${ }^{37}$ One of his examples of the forgone value that Microsoft could have obtained had it not placed restrictions that prevented OEMs, IAPs, and ICPs from offering Navigator was Microsoft's "provision of free space on its Channel Bar to ICPs who were willing to pay a positive price for placement on the Channel Bar." 38 Professor Sibley posited that Microsoft was willing to incur that opportunity cost to preserve its alleged OS monopoly: "[I]f these restrictions were aimed solely at expanding Microsoft's profits in Internetrelated markets by increasing IE browser usage, it could do better by capturing such profits through the price of its OS, or through selling Internet products tied to the OS (such as desktop space and ISP referral fees)." ${ }^{39}$

For reasons known only to the government, Professor Sibley was not used as an expert witness at trial. Thus, although Sibley introduced the monopoly preservation theory for the integration of Internet Explorer into Windows 98, his pretrial declaration did not become part of the trial record. Instead, Dr. Frederick R. Warren-Boulton and Professor Franklin M. Fisher became the government's principal proponents of that theory at trial. Dr. Warren-Boulton described the basis for the theory as follows:

Because of the nature of the barriers to entry created by network effects, the most likely long-term threat to Microsoft's monopoly power does not come directly from other operating systems, but rather from the spread of

36 Id. 745 (explaining that while browsers are distributed for free, a potential source of browser revenue comes from the sale of desktop space to IAPs).

37 Id. $\uparrow 48$.

$38 \quad$ Id.

39 Id. $ๆ 52$.
} 
cross-platform technologies, that can serve (like Microsoft's operating system) as a platform to which application developers write .... [A] though browsers may never develop into full-fledged operating systems, browsers can serve as a platform to which application developers write. Should application vendors use a browser platform other than the Windows platform, the applications barrier to entry that protects Microsoft's monopoly could be diminished, and competition in the PC operating system market created. ${ }^{40}$

Professor Fisher briefly addressed the issue of monopoly preservation in one footnote of his 1998 pretrial declaration, in which he concurred with Professor Sibley.41 At trial in 1999, however, Professor Fisher gave the leveraging theory greater emphasis. He concluded his direct testimony by saying: "Microsoft's conduct to create, preserve, and increase barriers to entry includes ... [t]ying its browser to the operating system, thereby requiring companies to enter successfully the already monopolized operating system market in order to compete successfully with Microsoft in supplying browsers and thus severely hampering Netscape in browser competition." 42 He did not, however, support that conclusion with any evidence.

In 2000, Professor Fisher, joined by Professor Daniel Rubinfeld (the Antitrust Division's chief economist during the initial prosecution of the Microsoft case), elaborated on the theory of using product integration to preserve a monopoly over PC operating systems. ${ }^{43}$ They claim that only in the absence of monopoly power is "bundling ... likely to be harmless and . . . serve legitimate business purposes, because bundling is not a rational anticompetitive strategy for a firm that lacks significant market power." 44 They contend that, because Microsoft has monopoly power over PC operating systems, it has an incentive to engage in anticompetitive and

40 Declaration of Frederick R. Warren-Boulton ๆๆ 8-9, United States v. Microsoft Corp., 147 F.3d 935 (D.C. Cir. 1998) (No. 98-1233).

41 Declaration of Franklin M. Fisher at 8 n.3, United States v. Microsoft Corp., 147 F.3d 935 (D.C. Cir. 1998) (No. 98-1233) [hereinafter Fisher Declaration] ("Microsoft's bundling of IE with the Windows software it distributes through retail channels is a similar effort to weaken Microsoft's browser competition in order to protect Microsoft's dominance in operating systems.").

42 Direct Testimony of Franklin Fisher ๆ 22, United States v. Microsoft Corp., (D.D.C. 1999) (No. 98-1233) [hereinafter Fisher Direct Testimony]; see also Franklin M. Fisher, The IBM and Microsoft Cases: What's the Difference?, 90 AM. ECON. REV. 180 (2000).

43 Franklin M. Fisher \& Daniel L. Rubinfeld, United States v. Microsoft: An Economic Analysis, in DiD MICROSOFT HARM CONSUMERS? TwO OPPOSING VIEWS 1, 28-29 (AEI-Brookings Joint Center for Regulatory Studies), available at http://www.aei.brookings.org/publications/books/consumers.pdf.

$44 \quad I d$. at 28-29; see also id. at 14-15, 23. 
unprofitable bundling of its Internet Explorer Web browser into the Windows operating system. .45

\section{Post-Chicago Procompetitive Explanations for the Bundling of Software Products}

The inclusion of Internet-related features in the operating system of a personal computer potentially makes the operating system a better product for Internet service vendors (ISVs) and consumers. Dean Richard Schmalensee observed in his written direct testimony for the 1999 Microsoft trial that bundling allows ISVs to "avoid having to write Internet-related code themselves[,] and consumers get Internet-related functionality with their operating system as well as applications programs that use this functionality in creative ways." 46 Bundling of features is common in software. For example, almost all word processing programs sold today have spelling checkers and grammar checkers built into them. Almost all spreadsheet packages have graphic components that enable users to convert spreadsheet data into pie charts and other graphics. In these cases, consumers are charged a single price for the product and do not pay extra for particular features of that product, even if earlier versions of that product did not include those features.

There are at least three economic reasons why firms in unquestionably competitive industries bundle features. 47 First, bundling allows the firm to respond to the diversity of valuations across software customers. Second, bundling stimulates demand for the firm's complementary features and products. Third, bundling generates revenue for the firm's ancillary services. In each case, bundling tends to increase demand even if the combination of

$45 C f$. at 14-15. It is not clear how Professors Fisher and Rubinfeld reconcile this argument with their concession that Microsoft's integration into Windows 98 of the Internet Explorer Web browser was not, by itself, necessarily anticompetitive. Id. at 23-26.

Other theoretical work on product integration examines how bundling can facilitate market segmentation or collusion among rival firms. See Jose Carbajo, David de Meza \& Daniel J. Seidmann, $A$ Strategic Motivation for Commodity Bundling, 38 J. INDUS. ECON. 283 (1990) (theorizing that, if firm $A$ bundles (and refuses to sell its products separately) while firm $B$ does not, then firm $A$ can target highvalue customers and leave firm $B$ to serve low-value customers not served by firm $A$ ); Yongmin Chen, Equilibrium Product Bundling, 70 J. BuS. 85 (1997) (theorizing that bundling can facilitate collusion by allowing rival firms to divide the market).

46 Schmalensee Direct Testimony, supra note 13, \235.

47 For a detailed discussion of these explanations, see Steven Davis, Jack MacCrisken \& Kevin Murphy, Integrating New Features into the PC Operating System: Benefits, Timing, and Effects on Innovation (Sept. 1998), at http://www.chipar.com/papers/integration.pdf. These consumer benefits should not be confused with network effects, which accrue with growth in the adoption of the particular product or standard. For a discussion of the network effect issues presented by the Microsoft case, see Howard A. Shelanski \& J. Gregory Sidak, Antitrust Divestiture in Network Industries, 68 U. CHI. L. REV. (forthcoming, 2001). 
features included in a product does not improve the performance or quality of the product in a strictly technical sense. Bundling tends to expand output and is therefore procompetitive.

\section{Responding to Diversity of Buyer Valuations for Software}

Bundling features together increases the number of consumers who will buy a product at a given price. Professors Yannis Bakos and Erik Brynjolfsson have observed that manufacturers can increase sales by increasing the diversity of buyers to which a product appeals, especially for information goods for which the additional cost to the manufacturer of including and distributing features is low. 48 Using E-library as an example, they explain why it makes economic sense for the vendor to provide "access to a bundle of 150 newspapers, 800 magazines, 2,000 works of literature, 18,000 photos, and thousands of additional information goods for a fixed price of $\$ 59.95$ per year for individual users." 49

One could make an analogous argument about the myriad sections contained in the Sunday New York Times. The marginal cost to the newspaper of providing the book review section to someone interested only in the sports section is zero. That condition holds regardless of the fact that the New York Review of Books can exist as a free-standing (unbundled) substitute for the New York Times Book Review. Indeed, the marginal cost to the New York Times of stripping the New York Times Book Review from the newspaper going to subscribers who read only the sports section would be astronomical. If priced on an avoided-cost basis, the stripped-down Sunday New York Times would cost more than the fully integrated newspaper.

Dean Schmalensee explains why this rationale is even more powerful for Microsoft's bundling of its Windows operating system and Internet Explorer Web-browsing software:

It is virtually costless to distribute Web-browsing software with the operating system. Although some users may not want to browse the Web or may not want to use the Web-browsing software that is included with the operating system, others will want to browse the Web with the included software. The operating system vendor can therefore increase sales by including Web-browsing software with the operating system. In fact, all major operating system vendors include Web-browsing software with the operating system at no extra charge. .50

48 Yannis Bakos \& Erik Brynjolfsson, Bundling Information Goods: Pricing, Profits and Efficiency, MGMT. SCI. (forthcoming, 2000).

49 Id.

$50 \quad$ Schmalensee Direct Testimony, supra note $46, \uparrow 241$. 
To support that analysis, Dean Schmalensee points to Central Point Software Inc.'s PC Tools and America Online's Internet service software as examples of how software firms use bundling to increase buyer diversity.51 For example, by including many tools in one package, Central Point Software attracted more consumers who found some combination of the tools to be worth the price. Similarly, for $\$ 21.95$ per month, AOL provides unlimited access to a wide range of services, including stock quotes, foreign exchange and commodity market information, weather reports, chat rooms, and e-mail, as well as Internet access. Indeed, AOL and other Internet portals can be regarded as electronic shopping malls that present the consumer with a preselected portfolio of services. One would expect Microsoft to integrate additional features into its Windows operating system for the same reason.

\section{Stimulating Demand for Complementary Products and Features}

Companies also have an incentive to bundle products if they are complements. Suppose that the demand for product $B$ increases if consumers also have product $A$. If a company produces both products, it has an incentive to lower the price of product $A$ to stimulate sales of product $B$ (This assumes, of course, that demand and cost elasticities are such that the profits lost from decreasing the price of $A$ are less than the profits gained by the increased sales of $B$ ). The company may actually have an incentive to give product $A$ away for free under some conditions. 52

Dean Schmalensee suggests several ways in which demand complementarities give Microsoft incentives to include Internet-related functionality in the Windows operating system. First, demand complementarities may plausibly exist between the operating system and applications software produced by ISVs. By including Internet-related functionality in the Windows operating system, Microsoft, in effect, increases the demand for the operating system that runs those applications. ${ }^{53}$ Second, demand complementarities may plausibly exist between the Windows operating system and applications software produced by Microsoft. By including Internet-related functionality in the operating system, Microsoft increases the demand for its own applications products that make use of this

51 Id. $\uparrow 238-41$.

52 For the classic example, see R. G. D. ALLEN, MATHEMATICAL ANALYSIS FOR ECONOMISTS 362 (1964). See also Richard Schmalensee, Monopolistic Two-Part Pricing Arrangements, 11 BELL J. ECON. 445 (1981). An analogous argument formed the basis for the economic critique of the antitrust rule against maximum resale price fixing in Albrecht v. Herald Co., 390 U.S. 145, 155 (1968), which the Supreme Court eventually overruled in State Oil Co. v. Khan, 522 U.S. 3 (1997).

53 Schmalensee Direct Testimony, supra note 13, 1244. 
Internet-related functionality. ${ }^{54}$ Third, demand complementarities may plausibly exist between various features within the Windows operating system. The demand for file management and hardware driver features of the operating system may be higher for users who use the Internet. Therefore, by providing Internet-related functionality at no additional cost, Microsoft can increase the demand for the other features of the Windows operating system and thereby increase sales. 55

\section{Generating Revenue from Ancillary Services}

Professor Benjamin Klein provides a third explanation for why Webbrowsing software is often distributed for free, either by itself, bundled with other products, or integrated into other products. ${ }^{56}$ In particular, Professor Klein explains that a firm that persuades consumers to use its Web-browsing software can obtain revenue from several different sources. ${ }^{57}$ For example, both Netscape and Microsoft sell Internet and intranet server software, Internet commerce applications, and Internet development tools. Similarly, Professors Carlo Shapiro and Hal Varian observe that the free distribution of a particular Web browser may enable the firm to generate "revenue streams 'adjacent' to the browser itself." 58 Professors Stephen Davis and Kevin Murphy reach the same conclusion. ${ }^{59}$ They argue that the demand for computer operating system software is highly complementary with applications software and Web use; that the marginal cost of software production is low, such that pricing these complementary functionalities at zero may be efficient; and that product integration may be the most efficient means of distribution for the consumer because it "eliminates the time and effort to obtain and install the zero-price item." 60

Dean Schmalensee observed in his 1999 testimony in the Microsoft trial that, during its first two years in business, Netscape earned 27.6 percent of its

\footnotetext{
54 Id. $\ 245$.

55 Id. $\ 246$.

56 Benjamin Klein, Microsoft's Use of Zero Price Bundling to Fight the Browser Wars, in COMPETITION, InNOVATION, AND THE MiCROSOFT MONOPOly (Jeffrey A. Eisenbach \& Thomas M. Lenard eds., 1999); see also Benjamin Klein, An Economic Analysis of Microsoft's Conduct, ANTITRUST, Fall 1999, at 38 .

57 See Klein, An Economic Analysis of Microsoft's Conduct, supra note 56, at 40,46 nn.22, 23.

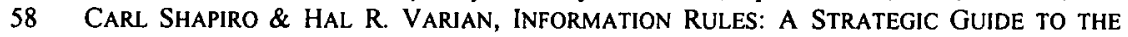
NETwORK ECONOMY 294 (1999), cited in William H. Page \& John E. Lopatka, The Dubious Search for "Integration" in the Microsoft Trial, 31 CoNN. L. REv. 1251, 1270 n.120 (1999).

59 See Steven J. Davis \& Kevin M. Murphy, A Competitive Perspective on Internet Explorer, 90 AM. ECON. REV. PAPERS \& PROC. 184 (2000).

60 Id. at 185.
} 
gross revenues from the sales of such software to corporations. ${ }^{61}$ Because advertising prices rise as more consumers are reached by the advertising, all other factors being held constant, Netscape can earn more advertising revenue from the "free" integration of Navigator into other software products. As a result of these ancillary revenue sources, Dean Schmalensee explains, the marginal opportunity cost to Microsoft of distributing another copy of Web-browsing software may be negative:

It costs virtually nothing to distribute another copy of the Web-browsing software. But that copy results in nontrivial additional revenue from the sales of ancillary products. It is plausible that the additional revenues exceed the direct cost of distribution, so that the effective cost of distribution of another copy is less than zero (that is, it "pays" rather than "costs" to distribute another copy) ... . The "negative marginal cost" of distributing Web-browser software is a further procompetitive reason for why Microsoft would include such software with its operating system. ${ }^{62}$

This reasoning contradicts the government's theory of predatory pricing claims in the current Microsoft case. As Howard Shelanski and I explain at length elsewhere,63 Judge Jackson rejected such reasoning when he concluded in April 2000 that Microsoft's integration of Internet Explorer into Windows 98 constituted attempted monopolization in violation of $\S 2$ of the Sherman Act.64

\section{Summation}

In recent years, economists have produced a variety of procompetitive and anticompetitive theories for product bundling, including software integration. The sophistication of these economic models counsels courts to consider carefully whether a given theory of product integration applies to the specific facts of an antitrust case. Although recent economic research provides grist for legal theories of anticompetitive behavior, that research also provides a rich basis upon which courts could find that consumer benefits might plausibly result from the bundling of software. The challenge to legal theory that such economic analysis presents is to formulate an antitrust rule for software integration that can reconcile existing case law

61 Schmalensee Direct Testimony, supra note 13, ๆ 247 (citing data from Netscape's SEC Form 10-Qs).

62 Id. $\ 248$.

63 Shelanski \& Sidak, supra note 47.

64 See Microsoft Findings of Law, supra note 5, at 38, 44. 
with the unique supply and demand characteristics that influence the nature of competitive rivalry in technologically dynamic markets.

\section{The Supreme Court's Jurisprudence on Tying After Jefferson Parish and Eastman Kodak}

A tie-in exists when, for two separate products, $A$ and $B$, a seller requires consumers to buy $B$ as a condition of selling them $A$. The Supreme Court's classic definition in Northern Pacific states that a tie-in is "an agreement by a party to sell one product but only on the condition that the buyer also purchases a different (or tied) product, or at least agrees that he will not purchase that product from any other supplier."65 As a matter of blackletter law, four elements are required to establish a per se unlawful tiein: (1) two separate products exist, (2) the sale of the tying product is conditioned on the purchase of the tied product, (3) the defendant has market power in the tying product, and (4) the tie-in forecloses a substantial amount of potential sales of the tied product.66 Logically, of course, if the defendant can show that two separate products do not exist, then the three remaining elements of the four-part test evaporate. For that reason, the concept of product integration (or its converse, product "separateness") is the linchpin of the antitrust jurisprudence on tying arrangements. That question is also one of great economic subtlety, for it implicates fundamental theoretical questions of consumer demand and consumer welfare, particularly when network effects are present.

Even within traditional antitrust doctrine, if two separate products are shown to exist, product integration through a tie-in is not necessarily unlawful. For years, the per se rule against tie-ins has not really been a per se rule at all, as the courts have created various defenses for product integration that can be shown in some respect to enhance consumer welfare or increase economic efficiency.67 A specialized antitrust rule for the integration of

65 N. Pac. Ry. v. United States, 356 U.S. 1, 5-6 (1958).

66 E.g., Eastman Kodak Co. v. Image Tech. Servs., Inc., 504 U.S. 451, 462 (1992); Multistate Legal Studies, Inc. v. Harcourt Brace Jovanovich Legal \& Prof'l Publ'ns, Inc., 63 F.3d 1540, 1546 (10th Cir. 1995).

67 "When the economic advantages of joint packaging are substantial the package is not appropriately viewed as two products, and that should be the end of the tying inquiry. The lower courts largely have adopted this approach." Jefferson Parish Hospital District No. 2 v. Hyde, 466 U.S. 2, 40 (O'Connor, J., concurring) (citing Foster v. Mar. State Sav. \& Loan Ass'n., 590 F.2d 928, 930-33 (D.C. Cir. 1978); Response of Carolina, Inc. v. Leasco Response, Inc., 537 F.2d 1307, 1330 (5th Cir. 1976); Kugler v. AAMCO Automatic Transmissions, Inc., 460 F.2d 1214 (8th Cir. 1972); ILC Peripherals Leasing Corp. v. Int'] Bus. Machs. Corp., 448 F. Supp. 228, 230 (N.D. Cal. 1978); United States v. Jerrold Elecs. Corp., 187 F. Supp. 545, 563 (E.D. Pa. 1960), affd per curiam, 365 U.S. 567 (1961)). "Consumer welfare and economic efficiency are not synonymous. Economic efficiency connotes that state of affairs in which ... no opportunity to promote the general welfare has been neglected. Such an opportunity is defined as the 
software would be a natural step in that progression. ${ }^{68}$ But what would such a rule be?

Currently, the Supreme Court's jurisprudence on tying cannot say. The most recent precedents under $\S 1$ of the Sherman Act are the Court's 1984 decision in Jefferson Parish Hospital District No. 2 v. Hyde ${ }^{69}$ and its 1992 decision in Eastman Kodak Co. $v$. Image Technical Services, Inc. ${ }^{70}$ Unfortunately, that jurisprudence has limited utility when applied to product integration in a technologically dynamic network industry such as software. It therefore seems inevitable that the Court will need to revisit the law of tying in the specific context of software integration..$^{71}$

\section{A. The Jefferson Parish Decision}

In Jefferson Parish, a hospital required its patients to seek services from one firm of anesthesiologists.72 Although it was "far too late in the history of our antitrust jurisprudence to question the proposition that certain tying arrangements pose an unacceptable risk of stifling competition and therefore are unreasonable 'per se,"'73 the Court, in an opinion by Justice Stevens, also acknowledged that "not every refusal to sell two products separately can be said to restrain competition." 74 Illegal tying arrangements were distinguished by "the essential characteristic of . . . forc[ing] the buyer into the purchase of a tied product that the buyer either did not want at all, or might have preferred to purchase elsewhere on different terms." 75 In contrast, tying arrangements used to maximize a seller's return on the tying product, were not subject to per se condemnation, for they were not necessarily coercive or anticompetitive. 76

availability of a course of action that will benefit at least some individuals, in their own estimation, in a way not achieved at the expense of others." WILLIAM J. BAUMOL \& J. GREGORY SIDAK, TOWARD COMPETITION IN LOCAL TELEPHONY 23-24 (1994). Consumer welfare is distinguishable from economic efficiency in the sense that the latter connotes "the maximization of the general welfare of consumers and producers - that is, the maximization of the sum of consumers' surplus and producers' surplus. Often this criterion is referred to in the abbreviated form "consumer welfare maximization."' $I d$. at 26.

$68 C f$. Sidak, supra note 6 (advocating in 1983 a rule of per se legality for product innovations achieved through product integration)

69466 U.S. 2 (1984).

70504 U.S. 451 (1992)

71 I wholeheartedly agree with Professor Lessig when he predicts: "In the context of tying generally, and the tying of software products in particular, it is my view that there is a significant probability that the Supreme Court will modify current doctrine." Lessig Amicus Brief, supra note 4, at 7.

72466 U.S. at 6.

73 Id. at 9.

74 Id. at 11

75 Id. at 12

$76 \quad$ Id. at 14 
Insofar as no Justice dissented, Jefferson Parish might be regarded as an easy case. However, the concurring opinions reveal that the real debate between the Justices concerned the wisdom of the per se rule. ${ }^{77}$ In her concurring opinion, Justice O'Connor (joined by Chief Justice Burger and Justices Rehnquist and Powell) criticized the per se rule for requiring courts to conduct a fact-intensive inquiry into the real-world economic effects of tie-ins while denying them the ability to permit tie-ins that were shown to be beneficial. ${ }^{78}$ Justice O'Connor's approach would evaluate tying arrangements according to the rule of reason, which would invalidate such arrangements in the "rare cases where power in the market for the tying product is used to create additional market power in the market for the tied product."79 Plaintiffs would have to meet a higher threshold for courts to consider invalidating a tie-in per se, having to show that a seller had market power in the tying-product market; 80 that there existed a "substantial threat that the tying seller will acquire market power in the tied-product market"81; and a "coherent economic basis for treating the tying and tied products as distinct." 82 Finally, even if a plaintiff could make such a showing, a tie-in could still be permitted if its economic benefits exceeded its harms. ${ }^{83}$

The most salient feature of Jefferson Parish - and the sharpest point of disagreement between the majority opinion and the concurring opinionswas the question of how to determine if the tying arrangement involved two products or only one. According to the majority, "the answer to the question whether one or two products are involved turns not on the functional relation between them, but rather on the character of the demand for the two items." ${ }_{44}$ Under the majority's approach, two products are deemed to exist if sufficient demand exists to create distinct and separate markets for both the tying and the tied products. ${ }^{85}$ Justice O'Connor rejected such reasoning. She (and three other Justices) thought it absurd to apply the majority's analysis to integrated products:

All but the simplest products can be broken down into two or more components that are "tied together" in the final sale. Unless it is to be

77 Compare id. at 32 (Brennan, J., concurring) (endorsing the per se rule), with id. at $32-47$ ( $\mathrm{O}^{\prime}$ Connor, J., concurring) (opposing the per se rule in favor of an analysis of tie-ins under the rule of reason).

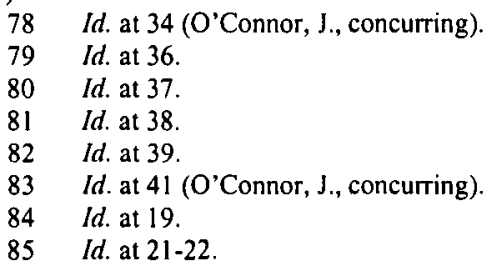


illegal to sell cars with engines or cameras with lenses, this analysis must be guided by some limiting principle .... . Even when the tied product does have a use separate from the tying product, it makes little sense to label a package as two products without also considering the economic justifications for the sale of the package as a unit. When the economic advantages of joint packaging are substantial the package is not appropriately viewed as two products, and that should be the end of the tying inquiry. 86

In Eastman Kodak, the Court would revisit this issue of how to determine whether an alleged tie-in involved two products or one.

\section{B. The Eastman Kodak Decision}

At issue in Eastman Kodak was whether, for tying law, replacement parts and repair service for Kodak photocopiers are separate products. 87 In an opinion by Justice Blackmun, the Court not only found that parts and service were distinct markets, ${ }^{88}$ but also rejected Kodak's claim that, even if it held a monopoly in the market for replacement parts for Kodak photocopiers, interbrand competition among photocopier manufacturers made it impossible for Kodak to exploit that market power. ${ }^{89}$

Eschewing Justice O'Connor's reasoning in Jefferson Parish, the Court first found that parts and service could plausibly be considered separate products because there was "sufficient consumer demand so that it is efficient for a firm to provide service separately from parts." 90 The Court appeared to have little patience for the seemingly intuitive claim that parts and service could not constitute distinct markets because there was no demand for parts separate from service: "By that logic, we would be forced to conclude that there can never be separate markets, for example, for cameras and film, computers and software, or automobiles and tires." 91 Kodak, the Court observed, sold service with parts to some, service without parts to others, and parts without service to yet other consumers.92

In a dissent joined by Justices O'Connor and Thomas, Justice Scalia criticized the majority's reliance on "sufficient consumer demand" to find that replacements parts and repair service were distinct markets. ${ }^{93}$ Not only

86 Id. at 39-40 (O'Connor, J., concurring).

87504 U.S. at 459

88 Id. at $462-64$.

89 Id. at $465-78$.

90 , Id. at 462.

91 Id. at 463.

92 Id.

93 Id. at 494 n.2 (Scalia, J., dissenting). 
was the repair service that Kodak provided "inherently associated with the parts," 94 but customers tended to demand the two items in fixed proportions, buying "one part with one unit of service necessary to install the part."95 Quoting Professors Areeda and Kaplow, Justice Scalia observed: "When that situation obtains, "no revenue can be derived from setting a higher price for the tied product which could not have been made by setting the optimum price." 96 Such considerations "strongly suggest[ed] that Kodak parts and the service involved in installing them should not be treated as distinct products for antitrust tying purposes." 97

Another disagreement between the majority and the dissenters was whether a firm could violate the Sherman Act by tying products in derivative aftermarkets (for example, tying service to replacement parts for Kodak photocopiers) when competition existed in the equipment foremarket. The majority was skeptical of Kodak's claim that competition among photocopier manufacturers prevented it from raising prices of services and parts for its machines. It is true that interbrand competition prevented Kodak from charging any supracompetitive price that it might have wanted for parts and services yet, such competition did not necessarily prevent Kodak from charging some supracompetitive price, since "[t]he fact that the equipment market imposes a restraint on prices in the after-markets by no means disproves the existence of power in those markets." 98

The check provided by interbrand competition upon exploitation of the intraband market, according to the Court, was attenuated by Kodak's horizontal relationship with competing providers of service.99 High information costs would prevent accurate life-cycle pricing, and most consumers, the majority feared, would be unable to calculate the total cost of equipment, replacement parts, and repair service.100 Furthermore, high switching costs also allowed Kodak to exploit its customers, for "consumers who already have purchased the equipment, and are thus 'locked in,' will tolerate some level of service-price increases before changing equipment brands."101

Justice Scalia, who had joined the Court since it had decided Jefferson Parish, found the majority's analysis unconvincing. He reasoned that

\footnotetext{
$94 \quad$ Id.

95 Id

96 Id. (quoting PHILLIP AREEDA \& LouIS KAPLOW, ANTITRUST ANALYSIS 706, ๆ 426(a) (4th ed. 1988)).

97 Id .

98 Id. at 471

99 Id. n. 18

100 Id. at 473.

101 Id. at 476.
} 
virtually every manufacturer of durable goods enjoys some form of market power with respect to unique products required for aftermarket support. However, lacking interbrand market power, a firm could not "raise derivative market prices generally by reducing quantity," because, if Kodak set supracompetitive prices for parts or service, consumers would purchase equipment from Kodak's competitors. ${ }^{102}$ The Court's concern over high information and switching costs was, in Justice Scalia's opinion, unfounded, for both kinds of transaction costs pervaded real-world markets without attracting the concern of antitrust law. ${ }^{103}$ Consequently, "[a] tie between two aftermarket derivatives does next to nothing to improve a competitive manufacturer's ability to extract monopoly rents from its consumers."104 Applying the per se rule to single-brand aftermarket ties would achieve nothing more than "releas[ing] a torrent of litigation and a flood of commercial intimidation." 105

\section{Analyzing Product Integration in Technologically Dynamic Markets}

Jefferson Parish and Eastman Kodak are not up to the task of guiding the law of tie-ins as it applies to product integration in technologically dynamic markets. Therefore, in this Part, I propose an approach to the law of tying arrangements, the overarching purpose of which is to instill within tying doctrine a filter that discriminates between technologically mature and technologically dynamic product markets. Traditional tying doctrine largely evolved from cases that fall in the former category. As a result, it should not be surprising that the existing precedent is ill-suited to cases that fall in the latter category. 106

My purpose in this Article is not to indict all of tying law, or even to argue that the per se rule be universally replaced with the rule of reason. Rather, taking the existing state of the law as given, I argue that courts must

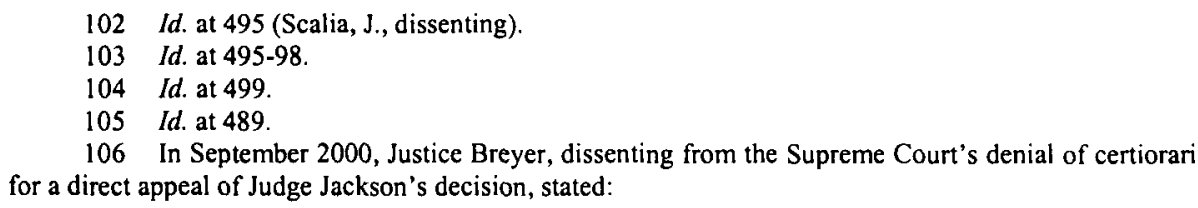

106 In September 2000, Justice Breyer, dissenting from the Supreme Court's denial of certiorari for a direct appeal of Judge Jackson's decision, stated:

The [Microsoft] case significantly affects an important sector of the economy-a sector characterized by rapid technological change. Speed in reaching a final decision may help create legal certainty. That certainty, in turn, may further the economic development of that sector so important to our Nation's prosperity.

Microsoft Corp. v. United States, 121 S. Ct. 25 (2000) (Breyer, J., dissenting from denial of certiorari). 
recognize the need to fashion a specialized tying rule for technologically dynamic markets.

\section{A. The Uninformative Preoccupation with "Separate Products"}

I heartily agree with Professor Lessig that, in cases of software integration, "what a 'product' is should not turn upon questions of metaphysics." 107 But I would take the point further. In a technologically dynamic market, it is misguided (and potentially harmful to consumer welfare) to dwell on the question of whether $A$ and $B$ are or are not "separate products" for purposes of tying law, since the very definition of the relevant product may be in constant flux. There are two broad difficulties with such inquiry.

First, merely to cast the legal analysis in terms of the separateness or cohesiveness of two "products" is to inject an implicit and biasing economic assumption that technology in the market in question is static rather than dynamic. My approach would defer to product integration that plausibly benefited consumers either through the achievement of economies of scope across two "products" (or functionalities) or through the stimulation of demand for an integrated (rather than disintegrated) product.

Second, the question of separate products has become an intellectual exercise that is required to do all the heavy lifting for an antitrust standard that otherwise fails to ask the pertinent economic questions that affect consumer welfare. This deficiency in the doctrinal intellectual tool kit becomes especially apparent in cases involving technologically dynamic markets, where courts seem to strain to prevent obvious consumer harm by engaging in increasingly metaphysical inquiries into the integration and separability of products. In essence, the courts, for lack of a hammer, are reduced to pounding a nail with a screwdriver.

\section{B. When Is a Market Technologically Dynamic?}

If a more tolerant antitrust rule is to apply in technologically dynamic markets, it is necessary to answer the anterior question of whether a particular market under consideration is "technologically dynamic." It is tempting to say that a technologically dynamic market, like pornography in the eyes of the late Justice Potter Stewart, is something that we know when we see it. Although the Microsoft litigation should not present a hard case of line drawing in this regard, future cases may be more subtle. How, then,

107 Lessig Amicus Brief, supra note 4, at 19. 
should a court make the threshold determination whether Jefferson Parish and Eastman Kodak are the starting point or the ending point for antitrust scrutiny of product integration?

Two kinds of questions seem informative. First, has the price-adjusted performance of the product improved markedly over time? Alternatively, has the price of the product fallen markedly, if one holds constant the level of performance? In particular, has the performance of the product improved at a rate faster than the rate of productivity growth in the economy as a whole? If the answer to these questions is yes, then it is possible, perhaps likely, that technological innovation (rather than exogenous changes in demand or government regulation) has been the impetus.

A second question concerns the novelty of the product at issue. Does the product reflect the creation of an entirely new source of consumer surplus? Has an entirely new demand curve come into existence? Is the product one for which virtually no demand at all existed only a few years before? One can recall the rate of adoption (or "diffusion") of new products, such as radios in the 1920s, televisions in the late 1940s and early 1950s, microwave ovens, video cassette recorders, and cellular telephones. One can readily imagine similar breakthroughs in product development in pharmaceuticals, medical devices, biotechnology, and financial services. If the product is one that is still in the steep portion of the S-shaped product life cycle curve, then it is appropriately regarded as being in a market that is technologically dynamic. In such a market, consumer knowledge is accumulating, and product demand is still immature and unstable.

In addition to these two lines of economic examination, there are other facts that might help to illuminate the degree to which a market is more properly characterized as technologically dynamic rather than technologically static. What are the numbers of patent applications and the expenditures on R\&D, both in absolute terms and in relation to the level of output and to the levels observed in other markets? What is the pattern of new business formations and business failures? Is there a highly mobile labor market for skilled workers? What is the market capitalization of firms relative to the replacement cost of their assets? To what extent are the stock market returns to firms in the market correlated with those of a diversified portfolio of industrial corporations, such as those in the Dow Jones Industrial Index? The answers to such questions will supply facts that will elucidate the two economic questions posed above. 


\section{Four Proposed Steps for Evaluating Product Integration in Technologically Dynamic Markets}

A more specialized antitrust analysis of software integration would begin after the four elements of Jefferson Parish and Eastman Kodak had been proven. Then a court would ask four additional questions.

\section{Step One: Is the Market Technologically Mature or Technologically Dynamic?}

The first additional step in my proposed approach asks whether the market in question is technologically mature or technologically dynamic. If the market is technologically mature, then the traditional four-part test for tie-ins used in Jefferson Parish and Eastman Kodak applies. In such a market, products are well-defined, both by the consumer demand that they satisfy and by the production technology through which firms supply them. In such a market, as opposed to a technologically dynamic market, it is far more likely that a court can conclude with confidence that the tying product and the tied product are indeed separate products. Jefferson Parish's focus on the "character of demand" is coherent and judicially manageable. Hence, the Supreme Court's signal cases on tie-ins have involved rather prosaic combinations of goods, such as business machines and punch cards, ${ }^{108}$ mimeograph equipment and ink, ${ }^{109}$ salt machinery and salt.110

If, on the other hand, the market is technologically dynamic, additional elements are required before an instance of product integration can be found to violate $\S 1$ of the Sherman Act. In such a case, competition exists for the market in a Schumpeterian sense.111 Consumer welfare will depend to a greater extent on rivalry with respect to nonprice variables, such as quality and innovation. ${ }^{112}$ As noted earlier, competition for the market can be viewed as a contest to define entirely new demand curves or to push existing demand curves outward with vastly improved combinations of price and performance. Jefferson Parish's analysis of the "character of demand" is incomplete and ambiguous. Consumers and producers are still in the midst of discovering what the "character of demand" is likely to be. Any tying rule that ignores this condition of demand uncertainty runs a great risk of harming consumers.

\footnotetext{
108 Int'l Bus. Machs. Corp. v. United States, 298 U.S. 131 (1936).

109 Henry v. A.B. Dick Co., 224 U.S. 1, 26, 32 (1912).

110 Int'l Salt Co. v. United States, 332 U.S. 392 (1947).

111 See Shelanski \& Sidak, supra note 47.

112 See Richard Schmalensee, Antitrust Issues in Schumpeterian Industries, 90 AM. ECON. REV. PAP. \& PROC. 192 (2000).
} 
It bears emphasis that one need not cast the Schumpeterian nature of competition in software markets as a consideration that speaks solely (or even principally) to whether, for purposes of analyzing tying claims, two kinds of functionalities constitute one product or two. Both the Areeda treatise and Professor Lessig's amicus brief propose variants on the Jefferson Parish rule that would consider the technologically dynamic nature of the market; having considered such evidence, however, both would perpetuate the stilted reasoning of tying doctrine by acting as though such evidence tells us something useful about the "single product" question and nothing else.113 That is the wrong approach. It is more productive to candidly assert that the Court's existing tying jurisprudence is inadequate to address technologically dynamic markets, rather than to suggest that a subtler meaning of "single product" is the means by which to recognize the importance in the law of Schumpeterian competition. Professor Hovenkamp wisely does so in the 1999 supplement to the Areeda treatise. 114

2. Step Two: Is It Plausible that Consumers Will Benefit from Subadditive Costs or Superadditive Demand Resulting from Product Integration?

As a second additional step, the court asks whether it is plausible that consumers will benefit from the product integration in question. As I will show in Part V, this question is simply a restatement of the first component

113 At points in his amicus brief, Professor Lessig seems to recognize the failure of existing tying doctrine to incorporate considerations of Schumpeterian competition for the market. He notes that the Areeda treatise proposes to modify Jefferson Parish in the case of computer software by considering no less than six mitigating "single product" rationales. Lessig Amicus Brief, supra note 4, at 32. (Of course, any rule with six possible loopholes is no rule at all.) One such rationale is the "Competitive Market Practices" (CMP) rationale, which asks whether competitive firms in the market bundle products in the same manner as the defendant firm. See 10 Phillip AREedA, EINER Elhauge \& Herbert HovenKamp, ANTITRUST LAW $\S 1744$ (1996). In a Schumpeterian market, however, it is quite possible and no reason for alarm that there will be no observable competitors at any given moment, because competition for the market occurs sequentially. Professor Lessig observes, and I agree, that: "If the defendant is the first to bundle this new functionality, then there would be no historical practice against which to compare the bundle. And if there were no historical practice, then the CMP test would no longer be a useful proxy for determining whether it was efficient to provide the two items separately." Lessig Amicus Brief, supra note 4, at 32. For that reason, the Areeda treatise proposes the "New Product" rationale, which asks whether "the defendant's bundle causes the items to operate together in a way that had not been tried before." AREEDA, Elhauge \& HovenKamP, supra, 1746a. But, again, the focus is on whether the bundle of items should be deemed a single product.

114 Phillip E. AReEda \& Herbert HovenKamp, Antitrust law: An ANalysis of ANTITRUST PRINCIPLES AND THEIR APPLICATION I 1746.1a (Supp. 1999) [hereinafter AREEDA \& HOVENKAMP 1999 SUPPLEMENT] ("The problem raised in the Microsoft [II] case illustrates the artificiality of the separate products requirement ... for purposes of measuring the anticompetitive effects of Microsoft's bundling practice, it is of little importance whether the Windows 95 operating platform and the Intemet browser were once sold separately."). 
of the D.C. Circuit's Microsoft II rule. Such consumer benefits can come from lower costs, increased demand, or both.

Increased demand results from product integration if there is superadditivity of demand across two outputs, $A$ and $B$, when they are produced as an integrated product. The increased demand may result because the product definition has changed as a result of the integration in a manner that produces more satisfaction (utility) for consumers. Otherwise, it may result because the integration of $A$ and $B$ reduces the cost to the consumer of engaging in product assembly or integration on her own. Or, the increased demand may result from some factor that is impossible to predict a priori, but which is reflected, ultimately and objectively, in consumers' higher willingness to pay.

Lower costs result from product integration if there is subadditivity of costs across two outputs, $A$ and $B$. This efficiency will unambiguously benefit consumers, because even a monopolist's profit-maximizing price will fall in the face of declining costs. Subadditivity of costs is present if a firm with a given cost function "has lower costs than would an allocation of output among two or more firms using the same cost function."115 In other words, it is more efficient for the single firm to produce $A$ and $B$ as an integrated product than it is for the firm (or multiple firms) to produce $A$ separately from $B$. Such efficiencies are also known as economies of scope. The firm's technology is said to exhibit economies of scope when it is less costly for one firm to produce a set of goods jointly than for distinct firms to produce individual goods or subsets of goods separately. 116

The analysis of cost subadditivity also implicitly answers the question of who-the producer or the consumer-is the more efficient integrator of individual functionalities. As I will show in Part V, that information responds to the second component of the D.C. Circuit's Microsoft II rule. Although it may be feasible for the consumer to integrate separate functionalities, the consumer may not be the lower-cost integrator. The superior efficiency of the producer is a factual question whose answer depends on economies of scale and scope, as well as learning-by-doing effects that allow the producer's unit cost of product integration to fall over time, with its level of cumulative output. Furthermore, as income levels rise (either over time or across demographic segments of the population of consumers), the opportunity cost

115 J. GREgory SidAK \& DANIEl F. SPUlber, DEREgulatory TAKINGS AND the REgulatory CONTRACT: THE COMPETITIVE TRANSFORMATION OF NETWORK INDUSTRIES IN THE UNITED STATES 20 (1997).

116 Id. at 22. "[A]lthough natural monopoly implies economies of scope, the converse is not the case. Most multiproduct firms derive economies of scope from joint production; it is a primary motivation for companies to diversify their product offerings. That achievement of economies of scope does not imply that those companies could serve their entire markets at lower cost than two or more firms." Id. 
of the consumer's time also rises, such that the consumer's implicit cost of integrating products rises. Thus, rising income levels make the division of labor (by which the producer's specialized capital and labor integrate products) more significant. I will revisit this question of feasible versus efficient integration of software products by the consumer when, in Part V, I analyze the D.C. Circuit's software integration rule in Microsoft II.117

Over what possible states of the world should an antitrust court evaluate a claim of consumer benefit from product integration? Is a consumer benefit an improvement over an actual market outcome that previously existed? Or should a consumer benefit also be evaluated relative to other hypothetical states of the world? The answer to this question is important because it reveals how one regards the proper role of antitrust law as an instrument of economic policy. Although the government agreed that there was some benefit to Microsoft's product integration, it seemed to regard such a benefit as insufficient or illegitimate because, on one account, the integration created a monopoly that impeded competition and therefore denied consumers access to some alternative market structure in which the government hypothesized that software would be even more advanced and prices even lower than in the outcome that Microsoft had actually produced through its integration of software.

This conception of the consumer-welfare standard in antitrust law is misguided. It turns antitrust into a forward-looking industrial policy. Antitrust intervention becomes an instrument of central planning that embodies the fatal conceit that government enforcers and federal judges can divine and rank alternative outcomes in highly uncertain markets subject to rapid technological change.118 To prevent antitrust from being given that unrealistic responsibility, it is appropriate for a court to reject hypothetical comparisons and instead regard a consumer benefit as any current market outcome that represents an improvement over a previous market outcome. In the case of the integration of software products such as Windows and Internet Explorer, the proper question, as the D.C. Circuit reasoned in Microsoft II, ${ }^{119}$ concerns the consumer benefits of the integrated product as it has been designed, not as it could have been designed.120

117 See infra note 172 and accompanying text.

118 See J. Gregory Sidak, Antitrust and the Federal Software Commission, JOBS \& CAPITAL, Winter 1997, at 18 .

119 See Microsoft II, 147 F.3d 935, 950 n.13 (D.C. Cir. 1998).

120 Professor Lessig reads the Areeda treatise to pose a different consumer-welfare question from that posed by the D.C. Circuit in Microsoft II: Could the producer have designed separable products so that the consumer could integrate them and achieve the same benefits as if the producer had done the integration? Lessig Amicus Brief, supra note 4, at 7 (citing 9 AREEDA, ANTITRUST LAW \$1730 (1991)). 
3. Step Three: Is It Probable That Integration Will Preserve a Monopoly over the Tying Product by Substantially Reducing Competition from the Tied Product?

Some may argue that, even though an instance of product integration benefits consumers by achieving subadditive costs, superadditive demand, or both, such integration will preserve a monopoly that the producer possesses over the tying product. This concern rests on the theoretical possibility that software integration may tend to preserve a monopoly over operating systems by discouraging the development of alternative platforms made possible by middleware. And, as I will explain in Part VI, this consideration also responds to Professor Lessig's recommendation that courts consider whether the tying and tied product are partial substitutes.

Of course, if no reduction in competition in the tying product's market is discernible, then the inquiry ceases and the tying arrangement is deemed lawful. On the other hand, if a reduction in competition is discernible, then the court's inquiry advances to the next step, which concerns the ultimate impact of the product integration on consumer welfare.

4. Step Four: Will the Reduction, If Any, in Competition Cause Consumer Welfare Losses That Exceed the Consumer Welfare Gains from Subadditive Costs or Superadditive Demand?

The final supplemental element to establish an unlawful tying arrangement in a technologically dynamic market is a net loss in consumer welfare. Unless the plaintiff can show that consumer welfare fell under the integration of the software products or functionalities in question, there should be no finding of liability under $\S 1$ of the Sherman Act. As a factual matter, this determination requires the court to compare (1) the welfare losses to consumers from reduced competition in the market for the tying product with (2) the welfare gains to consumers from the creation of subadditive costs, superadditive demand, or both. A finding of liability follows only if the first amount outweighs the second.

This kind of welfare tradeoff is familiar in antitrust law. In the late 1960s, Professor Oliver E. Williamson demonstrated the effects on consumer welfare of a merger that restricts output (by raising prices) and lowers marginal costs (by achieving certain productive efficiencies).121 To defend a merger, according to Professor Williamson, the merging parties must demonstrate that the cost savings achieved through greater efficiencies

121 Oliver E. Williamson, Economies as an Antitrust Defense: The Welfare Tradeoffs, 58 AM. ECON. REV, 18, 21 (1968). 
exceed the deadweight loss (the amount above costs that consumers would be willing to pay for the lost output) to consumers. The Department of Justice and the Federal Trade Commission have since embraced the Williamsonian welfare tradeoff for both vertical122 and horizontal merger analysis. 123 Judge Robert Bork has argued that Williamson's insight can be extended to any antitrust analysis.124 Thus, an application of the Williamson's welfare tradeoff in the context of software integration presents neither a novel nor a controversial mode of antitrust analysis.

\section{Summation}

If they are to advance consumer welfare, antitrust decisions concerning software integration require a more sophisticated model of analysis than Jefferson Parish and Eastman Kodak can provide. In addition to examining the four traditional elements of unlawful tying employed in Jefferson Parish and Eastman Kodak, a court should ask four additional questions. First, is the market technologically mature or technologically dynamic? Second, is it plausible that consumers will benefit from subadditive costs or superadditive demand resulting from product integration? Third, is it probable that integration will preserve a monopoly over the tying product by substantially reducing competition from the tied product? Fourth, will the reduction, if any, in competition cause consumer welfare losses that exceed the consumer welfare gains from subadditive costs or superadditive demand? By asking these four additional questions, a court will be more certain that its assessment of the lawfulness of software integration will promote consumer welfare.

122 U.S. DEPARTMENT OF JUSTICE HORIZONTAL MERGER GUIDELINES 1984, $\$ 4.0$ (stating that as in the case of horizontal mergers, the Department will consider expected efficiencies in determining whether to challenge a vertical merger).

123 Id. "'Because the antitrust laws, and thus the standards of the Guidelines, are designed to proscribe only mergers that present a significant danger to competition, they do not present an obstacle to most mergers. As a consequence, in the majority of cases, the Guidelines will allow firms to achieve available efficiencies through mergers without interference from the Agency.").

124 Judge Bork writes: "[Williamson's framework] can be used to illustrate all antitrust problems, since it shows the relationship of the only two factors involved, allocative inefficiency and productive efficiency. The existence of these two elements and their respective amounts are the real issues in every properly decided antitrust case. They are what we have to estimate-whether the case is about the dissolution of a monopolistic firm, a conglomerate merger, a requirements contract, or a price fixing agreement." ROBERT H. BORK, THE ANTITRUST PARADOX: A POLICY AT WAR WITH ITSELF 108 (1978). 
IV. The D.C. Circuit's Software Integration Rule Announced in Microsoft II

My proposed antitrust rule for software integration can be reconciled with significant lower court jurisprudence and academic proposals. In this Part, I examine the leading case on product integration for software, United States v. Microsoft Corp. (Microsoft II). 125

In that 1998 decision, the U.S. Court of Appeals for the District of Columbia Circuit interpreted, in an opinion by Judge Stephen F. Williams, $\S$ IV(E)(i) of the Justice Department's 1994 consent decree with Microsoft, a provision that prohibited Microsoft's tying of programs to its Windows operating system. The D.C. Circuit read $\S$ IV(E) to allow product integration if "the combination offered by the manufacturer [is] different from what the purchaser could create from the separate products on his own" and if the combination is "better in some respect." 126 The court further said that "[t]he question is not whether the integration is a net plus but merely whether there is a plausible claim that it brings some advantage."127 The D.C. Circuit relied on general antitrust principles to interpret the anti-tying provision in the consent decree, though it left open the question "[w]hether or not this is the appropriate test for antitrust law generally." 128 The D.C. Circuit thus evaluated in 1998 the relevance of Jefferson Parish and Eastman Kodak to the precise kind of software integration issue that produced the government's complaint later that year against Microsoft over the integration of the Internet Explorer Web browser into the Windows 98 operating system. I argue that, in cases decided according to antitrust law rather than according to principles of interpretation for consent decrees, the D.C. Circuit's rule in Microsoft II, as clarified by the four-step analysis presented above in Part IV, should indeed be the product integration rule for software.

\section{A. The Anti-Tying Provisions of the 1994 Microsoft Consent Decree}

The D.C. Circuit in Microsoft II was not construing antitrust precedent on a blank slate, but rather, it was interpreting $\S \operatorname{IV}(E)(i)$ of the Justice Department's 1994 consent decree with Microsoft, a provision that prohibited Microsoft's tying of software products to the Windows operating system. The court was thus ostensibly interpreting a contractual provision in light of the intentions of the contracting parties. Practically speaking,

$\begin{array}{ll}125 & 147 \text { F. } 3 d \text { d } 935 \text { (D.C. Cir. 1998). } \\ 126 & \text { Id. at } 949 . \\ 127 & \text { Id. at } 950 . \\ 128 & \text { Id. }\end{array}$


however, the court relied upon general antitrust principles and precedent in discerning both those intentions and the proper interpretation of the tying prohibition contained in the consent decree. The D.C. Circuit's analysis and underlying economic and legal rationales therefore apply equally to a claim of tying in violation of $\S 1$ of the Sherman Act or $\S 3$ of the Clayton Act. ${ }^{22}$

The D.C. Circuit's decision in Microsoft II arose from the district court's preliminary injunction prohibiting Microsoft from requiring computer manufacturers that were licensed to install the company's operating system software, Windows 95, to also secure a license to install Microsoft's Internet browser, Internet Explorer. ${ }^{130}$ Microsoft II concerned Windows 95 and the proper interpretation of a consent decree. The government's 1999 trial against Microsoft concerned Windows 98, and the government's theory of liability in that case was predicated on the Sherman Act. Nevertheless, the product tie-in issues in the two cases are for all practical purposes identical.

Because proper analysis of whether or not a product is truly integrated depends on specific facts, it is necessary to set forth the basic facts of Microsoft II in some detail. The case arose from Microsoft's practices in marketing its Windows 95 operating system. The D.C. Circuit described an operating system as "the central nervous system of the computer, controlling the computer's interaction with peripherals such as keyboards and printers."131 In the case of Windows 95, Microsoft "integrate[d] a DOS shell with a graphical user interface," which supplied the now-familiar "technology by which the operator performs functions not by typing at the keyboard but by clicks of his mouse." 132 The court distinguished operating systems from "platforms:"

Operating systems also serve as "platforms" for application software such as word processors. As the word "platform" suggests, the operating system provides a basic support structure for an application via "application programming interfaces" ("APIs"), which provide general functions on which applications can rely. Each operating system's APIs are unique; hence applications tend to be written for particular operating systems. ${ }^{133}$

The D.C. Circuit noted that "[t]he primary market for operating systems consists of original equipment manufacturers ('OEMs'), which make

129 For purposes of my analysis, I draw no distinctions between a tying claim under $\S 1$ of the Sherman Act and one under $\S 3$ of the Clayton Act, 15 U.S.C. $\S 14$ (2000).

130 Microsoft II, 147 F.3d at 938.

131 Id.

132 Id.

133 Id. at $938-39$. 
computers, install operating systems and other software that they have licensed from vendors such as Microsoft, and sell the package to end users," which could "be either individual consumers or businesses."134

In 1993, Novell, a competitor of Microsoft in the supply of operating systems for personal computers, filed a complaint with the European Commission's competition authority, then known as Directorate General IV, or DG IV. Novell argued that Microsoft was tying its MS-DOS operating system to the Windows 3.11 graphical user interface.135 Before the launch of Windows 95-which integrated the operating system with the graphical user interface-Microsoft marketed the MS-DOS operating system separately from the Windows graphical user interface. The Windows interface could also be used with other DOS products. Nevertheless, Novell's complaint centered on specific Microsoft marketing practices, such as per processor and per system licenses, which, according to Novell, created economic incentives for OEMs to preinstall MS-DOS and Windows 3.11.136 The complaint maintained that these practices permitted Microsoft to exercise market power over DOS-compatible graphical user interfaces to influence OEMs' choices in the DOS market, in which Novell marketed a competing product, DRDOS. 137

In 1994, the U.S. Department of Justice filed its own complaint against Microsoft, claiming that the company's licensing agreements with OEMs and other related practices were anticompetitive. The complaint was accompanied by a proposed consent decree intended to regulate those practices that had been negotiated between Microsoft, the Department, and DG IV. That decree included $\S$ IV(E), characterized by both Microsoft and the Department as an "anti-tying" provision:

Microsoft shall not enter into any License Agreement in which the terms of that agreement are expressly or impliedly conditioned upon:

(i) the licensing of any other Covered Product, Operating System Software product or other product (provided, however, that this provision in and of itself shall not be construed to prohibit Microsoft from developing integrated products); or

(ii) the OEM not licensing, purchasing, using or distributing any non-Microsoft product. 138 
After entry of the consent decree, Microsoft released its new browser, Internet Explorer 3.0, when it unveiled Windows 95 in July 1995. All copies of Windows 95 installed by OEMs included a version of Internet Explorer. Except for the few months that an injunction was in force, OEMs were required to install Internet Explorer as part of Windows. During the fall of 1997, OEMs had the option of installing Windows with either IE 3.0 or IE 4.0. Microsoft's contracts with OEMs generally require that they shift to the latest service release of Windows shortly after it is publicly released. Because of problems related to inventory in preparation for Christmas, however, OEMs may wait until January or February before switching to new releases issued in the fall. IE 4.0 was part of service release OSR 2.5, which was ready in September 1997. Microsoft made available to OEMs a CD with the patches needed to upgrade to IE 4.0/OSR 2.5. OEMs could install IE 4.0/OSR 2.5, or they could ship the CD with their systems for users to install. If OEMs did not install IE 4.0/OSR 2.5, however, the version of Windows 95 that was installed still contained IE 3.0 (which was an integral part of Windows).

In early 1998, the Department of Justice petitioned the U.S. District Court in Washington, D.C. to hold Microsoft in civil contempt for its bundled licensing of its Windows 95 operating system and IE 3.0, and to enjoin Microsoft not to employ similar agreements with respect to any version of IE in the future. The Department contended that Microsoft's licensing practice violated $\S \operatorname{IV}(E)(i)$ of the 1995 consent decree by effectively conditioning the license for Windows 95 on the license for IE 4.0, which, in the government's view, created a tie-in between the operating system and the Web browser. The timing of the Department's petition may have reflected an expectation that IE 4.0 would be the "killer" version of Explorer (praised in industry reviews), which the government wanted to stop before OEMs became contractually obligated to install IE 4.0 rather than IE 3.0. The district court granted the government's petition and issued a preliminary injunction forbidding Microsoft from licensing Windows 95 or any successor operating system on the express or implied condition that the OEM also install Microsoft's Web browser. ${ }^{139}$

139 United States v. Microsoft Corp., 980 F. Supp. 537 (D.D.C. 1997). The injunction was ambiguous, for it seemed to order as relief the very question at issue in the case. Apparently the parties were equally confused and, after further negotiations, they stipulated that Microsoft would be in compliance with the injunction "if it extended to OEMs the options of (1) running the Add/Remove Programs utility with respect to IE 3.x and (2) removing the IE icon from the desktop and from the Programs list in the Start menu and marking the file IEXPLORE.EXE 'hidden."' Microsoft $1 /, 147 \mathrm{~F} .3 \mathrm{~d}$ at 940-41. In fact, browser functionality itself persists, and can be summoned up either by entering four lines of code or by running any application (such as Quicken) that contains the code necessary to invoke the functionality. 


\section{B. May the Interpretation of an Antitrust Consent Decree Compromise the Goal of Consumer-Welfare Maximization That Is the Foundation of the Antitrust Laws?}

The rhetorical question that I pose as the caption for this section surely must be answered in the negative. The D.C. Circuit cautioned at the outset that its purpose was not to decide the antitrust issues that underlay the government's original complaint against Microsoft, but rather to interpret the bargain struck by the parties in their 1994 consent decree: "an antitrust consent decree cannot be read as though its animating spirit were solely the antitrust laws." 140 That caveat, however, turns out to be more jurisdictional than substantive in its import. It is clear that the D.C. Circuit did not approach (for indeed it could not approach) the interpretation of this antitrust consent decree as though the underlying goals and logic of antitrust law were irrelevant to the interpretative task at hand. The goals and logic of antitrust law were relevant because they defined the range of permissible interpretations for a "contract" between Microsoft and the Department of Justice that was to serve a public purpose.141 Indeed, it is worth asking whether the acceptance by a federal district court of an interpretation of an antitrust consent decree advanced by the Department of Justice that was indifferent to consumer welfare would constitute a usurpation of legislative

According to the D.C. Circuit, "It appears not to be disputed that these alternate modes of compliance do not remove the IE software code, which indeed continues to play a role in providing means of compliance simply enable the OEMs to make user access to IE more difficult." Id. at 941 . The court found this puzzling, observing that, "by allowing OEMs to conceal IE, rather than to refuse it, the remedy fits poorly with the Department's tying theory. A tie-in is not affected by the purchaser's ability to discard the tied good." Id. at 941 n.3.

140 Microsoft II, 147 F.3d at 946. The court, then quoted United States v. Armour \& Co., 402 U.S. 673, 681-82 (1971), for the proposition that: "The decree itself cannot be said to have a purpose; rather the parties have purposes, generally opposed to each other, and the resultant decree embodies as much of those opposing purposes as the respective parties have the bargaining power and skill to achieve." Id.

141 In an analogous manner, Justice Breyer reasoned in AT\&T Corp. v. Jowa Utils. Bd., $119 \mathrm{~S}$. Ct. 721 (1999), that the mandatory unbundling provisions of the Telecommunications Act of 1996, Pub. L. No. 104-104, 110 Stat. 56 (1996), though interpreted by the Federal Communications Commission under a public interest standard rather than the consumer welfare standard of the antitrust laws, must be read with the consumer welfare maximand of antitrust jurisprudence in mind, lest those statutory provisions produce absurd results that would harm consumers and thus, necessarily, disserve the public interest. lowa Utils. Bd., 119 S. Ct. at 753-54 (Breyer, J., concurring in part and dissenting in part); accord AREEDA \& HOVENKAMP 1999 SUPPLEMENT, supra note 114, ๆ 787; Jerty A. Hausman \& J. Gregory Sidak, $A$ Consumer-Welfare Approach to the Mandatory Unbundling of Telecommunications Networks, 109 YALE L.J. 417 (1999). Congress stated that the purpose of the Telecommunications Act of 1996 is to "promote competition and reduce regulation in order to secure lower prices and higher quality services for American telecommunications consumers and encourage the rapid deployment of new telecommunications technologies." Telecommunications Act of 1996, Pub. L. No. 104-104, preamble, 110 Stat. 56 (1996). 
power (in effect, a selective repeal of the Sherman Act and its goal of consumer-welfare maximization) by the executive and judicial branches, in violation the principle of the separation of powers. ${ }^{142}$

The precise question of whether Microsoft's integration of Windows 95 and Internet Explorer 4.0 violated the antitrust laws was not properly before the court and therefore would have been beyond its jurisdiction, as an Article III court, to decide. The case or controversy before the D.C. Circuit was not whether Microsoft had violated the Sherman Act. ${ }^{143}$ Nonetheless, it is equally clear that, in interpreting what both parties to the consent decree acknowledged to be an "anti-tying" provision that must be interpreted with "procompetitive goals in mind," 144 the court's substantive legal and economic reasoning was indistinguishable from the reasoning that it would have applied in deciding what would constitute an unlawful tying arrangement under then-current antitrust law. Although it is true that the consent decree did not constitute an acknowledgment by Microsoft that any of the prohibited practices were unlawful, or an acknowledgment by the government that any of the permitted practices were lawful, the intent of both parties nonetheless was necessarily informed-and necessarily constrainedpredominantly by antitrust law. Microsoft desired to compete as aggressively as possible within the limits of the law, whereas the government sought to restrain that competitiveness so that it remained within the same law.

Moreover, the parties could not have intended that their consent decree would advance purposes that would frustrate the consumer welfare maximization that is the objective of the antitrust laws. ${ }^{145} \mathrm{~A}$ consent decree manifesting such an intent would flunk the public interest test of the Antitrust Procedures and Penalties Act of 1974, better known as the Tunney Act, which establishes substantive and procedural standards for judicial approval of a proposed consent decree. ${ }^{146}$

The D.C. Circuit began by noting that $\S$ IV(E)(i) of the consent decree clearly must forbid a tie-in between Windows 3.11 and MS-DOS, the practice about which Novell complained. At the same time, the decree expressly recognized Windows 95 to be a single product that combined the functionalities of a graphical interface and an operating system. "Thus if the

142 Cf. Michael W. McConnell, Why Hold Elections? Using Consent Decrees to Insulate Policies From Political Change, 1987 U. CHI. LegaL F. 295.

143 See U.S. CONST. art. III, $\$ 2$ (case or controversy requirement)

144 Microsoft II, 147 F.3d at 946.

145 See, e.g., Nat'l Collegiate Athletic Ass'n v. Bd. of Regents, 468 U.S. 85, 107 (1984); Ariz. v. Maricopa County Med. Soc'y, 457 U.S. 332 (1982); Reiter v. Sonotone Corp., 442 U.S. 330,343 (1979); see also Stephen G. Breyer, Antitrust, Deregulation, and the Newly Liberated Marketplace, 75 CAL. L. REV. 1005 (1987).

14615 U.S.C. $\S \S 16(\mathrm{~b})-(\mathrm{h})(2000)$. 
relation between Windows 95 and IE is similar to the relation between Windows 3.11 and MS-DOS," the D.C. Circuit reasoned, "the link is presumably barred by $\S \operatorname{IV}(\mathrm{E})(\mathrm{i})$. On the other hand, ... if the Windows 95/IE combination is like the MS-DOS/graphical interface combination that comprises Windows 95 itself, then it must be permissible."147

The D.C. Circuit rejected the interpretations of both Microsoft and the Department of Justice because neither party could propose a textual interpretation of $\S \operatorname{IV}(\mathrm{E})(\mathrm{i})$ that was consistent with the facts of the Novell complaint that gave rise to the provision and the release of Windows 95, which was expressly permitted under the decree. The Department argued "that $\S$ IV(E)(i) prohibits Microsoft from bundling together a Covered Product and anything that 'Microsoft simultaneously treats' and 'antitrust law regards' as a 'distinct commercial product."'148 The Department further relied upon Jefferson Parish "for the proposition that products are distinct for tying purposes if consumer demand exists for each separately." 149 According to Judge Williams, however, "the Department's reading does not permit Windows 95," whereas "Microsoft's reading would provide zero relief to Novell, for it would allow Microsoft to bundle MS-DOS with Windows 3.11 as long as it did not license MS-DOS separately to OEMs."150 Each reading had to be erroneous: "Neither can be the correct interpretation of a provision that was intended to do both." 151

In addition, the D.C. Circuit rejected the attempt by both Microsoft and the Department to make Microsoft's own behavior with regard to the packaging and marketing of its products the dispositive factor. The court reached this conclusion by applying antitrust precedent and related economic reasoning:

This would be no defect if the behavior were in some way relevant to the economic principles of tie-ins. But it is not. The Department offers no theory as to how a seller's abstaining from separate marketing of the tied good might blunt the possible anticompetitive effects of bundling. It seems especially beside the point where the goods are complements used in fixed proportions. A monopolist who ties two such goods has no obvious reason to market the tied good separately: since all buyers of the tying good will also take the tied good, the residual market for the tied good will be minimal. If the concern is that the tie-in makes it more difficult for competitors to enter the market for the tying good (because

147 Microsoft II, 147 F.3d at 946.

148 Id.

149 Id.

150 Id. at 948.

151 Id. 
they must also offer the tied good), separate marketing of the tied good actually mitigates the posited harm by facilitating new entry into the market for the tying good. Thus both readings allow legitimation by behavior that is either irrelevant or actively harmful. ${ }^{152}$

The D.C. Circuit further observed in a footnote that the hospital in Jefferson Parish, a decision on which the government heavily relied, "surely did not offer the tied good (anesthesia) separately from the tying good (surgery), but this fact played no role in the Court's decision." 153

\section{Deriving the "Plausible Consumer Benefit" Rule from First Principles of Antitrust Law}

Frustrated by the inability of Microsoft and the Department of Justice to produce textually consistent interpretations of $\S$ IV(E)(i), the D.C. Circuit turned explicitly to antitrust law and related economic principles to resolve the dilemma:

The Department and DG IV were concerned with the alleged anticompetitive effects of tie-ins. Microsoft's goal was to preserve its freedom to design products that consumers would like. Antitrust scholars have long recognized the undesirability of having courts oversee product design, and any dampening of technological innovation would be at cross-purposes with antitrust law. Thus, a simple way to harmonize the parties' desires is to read the integration proviso of $\S \operatorname{IV}(\mathrm{E})(\mathrm{i})$ as permitting any genuine technological integration, regardless of whether elements of the integrated package are marketed separately. ${ }^{154}$

But what did the D.C. Circuit intend to use as its criteria in defining an "integrated package"? To "give substantive content to the concept of integration," the court defined an "integrated product" to be "most reasonably understood as a product that combines functionalities (which may also be marketed separately and operated together) in a way that offers advantages unavailable if the functionalities are bought separately and combined by the purchaser."'15s Applying this definition to Novell's complaint and the release of Windows 95, the D.C. Circuit explained that Microsoft's product integration "suggests a degree of unity, something

152 Id. (citing Grappone, Inc. v. Subaru of New England, 858 F.2d 792, 795-96 (Ist Cir. 1988)).

153 Id. at 948 n. 10.

154 Id. at 948 (emphasis added).

155 Id. 
beyond merely placing disks in the same box."156 Because Windows 95 combined functionalities in a way that the purchaser could not, the D.C. Circuit considered Windows 95 to be "an example of what Professor Areeda calls 'physical or technological interlinkage that the customer cannot perform."'157

In addition, the D.C. Circuit stressed, the integrated product must also be better in some respect from a consumer welfare standpoint. The D.C. Circuit conceded that " $[\mathrm{m}]$ anufacturers can stick products together in ways that purchasers cannot without the link serving any purpose but an anticompetitive one."158 The court emphasized that "[t]he concept of integration should exclude a case where the manufacturer has done nothing more than to metaphorically 'bolt' two products together, as would be true if Windows 95 were artificially rigged to crash if IEXPLORE.EXE were deleted." 159 In its elaboration of the criteria for an integrated product, the D.C. Circuit cautioned the district court-and, indeed, any court considering tying issues-about the limited competence of courts generally to conduct such an inquiry:

[W]e do not propose that in making this inquiry the court should embark on product design assessment. In antitrust law, from which this whole proceeding springs, the courts have recognized the limits of their institutional competence and have on that ground rejected theories of "technological tying." A court's evaluation of a claim of integration must be narrow and deferential. As the Fifth Circuit put it, "[S]uch a violation must be limited to those instances where the technological factor tying the hardware to the software has been designed for the purpose of tying the products, rather than to achieve some technologically beneficial result. Any other conclusion would enmesh the courts in a technical inquiry into the justifiability of product innovations." 160

156 Id. The Court emphasized that sham integration of products would fail antitrust scrutiny: "If an OEM or end user . . . could buy separate products and combine them himself to produce the 'integrated product,' then the integration looks like a sham. If Microsoft had simply placed the disks for Windows 3.11 and MS-DOS in one package and covered it with a single license agreement, it would have offered purchasers nothing they could not get by buying the separate products and combining them on their own." Id.

157 Id. at 949 (quoting 10 AREEDA, ElHAUGE \& HoveNKAMP, supra note 113, ๆ 1746b).

158 Id.

159 Id. (citing ILC Peripherals Leasing Corp. v. Int'l Bus. Machs. Corp., 448 F. Supp. 228, 233

(N.D. Cal. 1978) ("If IBM had simply bolted a disk pack or data module into a drive and sold the two items as a unit for a single price, the 'aggregation' would clearly have been an illegal tying arrangement."), aff'd per curiam sub nom. Memorex Corp. v. Int'l Bus. Machs. Corp., 636 F.2d 1188 (9th Cir. 1980).

160 Microsofi $I I, 147$ F.3d 935, 949-50 (D.C. Cir. 1998) (quoting Response of Carolina, Inc. v. Leasco Response, Inc., 537 F.2d 1307, 1330 (5th Cir. 1976)). 
Moreover, the D.C. Circuit made clear that its interpretation of an "integrated product" reflected not only the understanding of the parties to the consent decree, but also that "this understanding is consistent with tying law."161 In doing so, Judge Williams was careful to distinguish the issues relevant to software integration and the "separate consumer demand" standard used by the Supreme Court in Jefferson Parish and Eastman Kodak. The D.C. Circuit noted that the Supreme Court in Eastman Kodak based its analysis of separate consumer demand on efficiency considerations. The Justices

found parts and service separate products because sufficient consumer demand existed to make separate provision efficient. But we doubt that it would have subjected a self-repairing copier to the same analysis; i.e., the separate markets for parts and service would not suggest that such an innovation was really a tie-in. ... Similarly, Professor Areeda argues that new products integrating functionalities in a useful way should be considered single products regardless of market structure. 162

Although the D.C. Circuit reiterated that "the antitrust question is of course distinct," and that "the consent decree does not bar a challenge under the Sherman Act," the point made by Judge Williams for the D.C. Circuit-and by Judge Wald in her separate opinion, for that matter ${ }^{163}$-about the doubtful applicability of the Eastman Kodak rule of "separate consumer demand" to technological tying cases still holds.

The D.C. Circuit concluded its discussion of the applicable legal rule by emphasizing that its "analysis does not require a court to find that an integrated product is superior to its stand-alone rivals." 164 Judge Williams

161 Id. at 950.

162 Id. (citing Eastman Kodak v. Image Tech. Serv., Inc., 504 U.S. 451, 462 (1992); 10 AREEDA, ELHAUGE \& HOVENKAMP, supra note $113, \uparrow 1746 \mathrm{~b}$ ).

163 Judge Wald's separate opinion, concurring in part and dissenting in part, makes the same point:

Under antitrust law, two products are considered distinct if there exists "sufficient consumer demand so that it is efficient for a firm to provide [the first product] separately from [the second]." The difficulty in this case is that technological evolution can change the boundaries of what is "efficient." For example, Eastman Kodak cites cameras and film as examples of two functionally linked products for which there exist separate markets. But antitrust law presumably would not bar the development of digital cameras, which do not require film in any conventional sense.

Id. at 958 (Wald, J., concurring in part and dissenting in part) (quoting Eastman Kodak, 504 U.S. at 462) (citations omitted).

164 Microsoft II, 147 F.3d at 950; see also ILC Peripherals Leasing Corp. v. Int'l Bus. Machs. Corp., 458 F. Supp. 423, 439 (N.D. Cal. 1978) ("Where there is a difference of opinion as to the advantages of two altematives which can both be defended from an engineering standpoint, the court will not allow itself to be enmeshed "in a technical inquiry into the justifiability of product innovations."') (quot- 
further stated that the court's interpretation of law did not read $\S \operatorname{IV}(E)(i)$ to "put[ ] judges and juries in the unwelcome position of designing computers," an admonition that the D.C. Circuit credited to Professor Areeda. 165 "The question," Judge Williams concluded, "is not whether the integration is a net plus but merely whether there is a plausible claim that it brings some advantage." 166 Given the factual circumstances of the case, the D.C. Circuit reiterated that it was not called upon to announce a general principle of antitrust law: "Whether or not this is the appropriate test for antitrust law generally, we believe it is the only sensible reading of $\S$ IV(E)(i)."167

Although the procedural posture of Microsoft II would have made it inappropriate for the D.C. Circuit to announce that its standard applied to antitrust law generally, it is hard to imagine why the court's reasoning should deviate in any material respect from this approach in an antitrust case, given Microsoft II's grounding in antitrust principles and precedent. It is especially difficult to see why the appropriate legal reasoning should be any different for the tying and integrated product issues presented by the government's 1999 claims against Microsoft, given that the underlying factual and economic issues are virtually identical. If Microsoft's bundling of Internet Explorer 4.0 and Windows 95 was "consistent with tying law"168_and if that product integration was equivalent for antitrust purposes to a self-repairing copier or a digital camera, such that it was properly distinguished in Microsoft II from the facts of Jefferson Parish and Eastman Kodak-then the subsequent integration of Windows 98 and Internet Explorer 5.0 cannot logically be treated any differently.

\section{Application of the Product Integration Rule}

Applying its product integration rule to the facts before it in Microsoft II, the D.C. Circuit found that Microsoft "met the burden of ascribing facially plausible benefits to its integrated design as compared to an operating system combined with a stand-alone browser such as Netscape's Navigator."169 The

ing Leasco, 537 F.2d at 1330), aff'd per curiam sub nom. Memorex Corp. v. Int'1 Bus. Machs. Corp., 636 F.2d 1188 (9th Cir. 1980)

165 Microsoft 11,147 F.3d at 950 (citing 9 AREEDA, ANTITRUST LAW $\uparrow 1700$ j (1991))

166 Id. at 950 (emphasis added)

167 Id.

168 Id. at 950. The majority in Microsoft II stated: "We believe this understanding [of "integrated products'] is consistent with tying law. The Court in Eastman Kodak . .. , for example, found parts and service separate products because sufficient consumer demand existed to make separate provision efficient." Id. (citing 504 U.S. at 462; other citation omitted).

169 The D.C. Circuit explained: 
D.C. Circuit emphasized that even the government acknowledged that consumers benefited from Microsoft's product integration: "Even the Department apparently concedes that integration of functionality into the operating system can bring benefits; responding to a comment on the proposed 1994 consent decree (which the Department published in the Federal Register as required by the Tunney Act), it stated that 'a broad injunction against such behavior generally would not be consistent with the public interest." 170 But on its own, the D.C. Circuit's finding of plausible consumer benefits from Microsoft's product integration did not resolve the issue.

The second part of the D.C. Circuit's rule asks whether there is some reason that the two functionalities must be combined by Microsoft instead of by its customers. This was not a simple question, the court emphasized, of simply combining two CD-ROMs, though this possibility apparently was considered highly significant by the government. If multiple disk installations were equivalent to the customer's performing the combining of products, then no "software product could ever count as integrated."171 The D.C. Circuit rejected such logic in favor of the following:

[T] he only sensible answer is that the act of combination is the creation of the design that knits the two together. OEMs cannot do this: if Microsoft presented them with an operating system and a stand-alone browser application, rather than with the interpenetrating design of Windows 95 and IE 4, the OEMs could not combine them in the way in which Microsoft has integrated IE 4 into Windows 95 . They could not, for example, make the operating system use the browser's HTML reader to provide a richer view of information on the computer's hard drive-not without changing the code to create an integrated browser. This reprogramming would be absurdly inefficient. Consequently, it seems clear that there is a reason why the integration must take place at Microsoft's level.172

Incorporating browsing functionality into the operating system allows applications to avail themselves of that functionality without starting up a separate browser application. Further, components of IE 3.0 and even more IE 4-especially the HTML reader-provide system services not directly related to Web browsing, enhancing the functionality of a wide variety of applications. Finally, IE 4 technologies are used to upgrade some aspects of the operating system unrelated to Web browsing. For example, they are used to let users customize their "Start" menus, making favored applications more readily available. They also make possible "thumbnail" previews of files on the computer's hard drive, using the HTML reader to display a richer view of the files' contents.

Id. at $950-51$ (citation omitted).

170 Id. (quoting 59 Fed. Reg. 59,426, 59,428 (Nov. 17, 1994)).

171 Id.

172 Id. at 952 (citation omitted). 
This reasoning is consistent with the second step of the approach proposed in Part IV, 173 for the relative efficiency of the producer over the consumer as the ultimate integrator of functionalities will depend on the nature of cost subadditivity that results from the product integration. Again, it defies explanation why the "only sensible answer"174 to whether Windows 95 and Internet Explorer 4.0 constitute an integrated product would not also apply in a subsequent antitrust case not covered by the consent decree. Given the technical interconnection of code cited by the D.C. Circuit and given the consistency of Microsoft II with antitrust and economic principles, how can the product be "integrated" for purposes of an anti-tying provision in a consent decree and consistent with antitrust law, yet somehow remain "disintegrated" for purposes of $\S 1$ of the Sherman Act? Plainly, it cannot.

\section{E. Judge Wald's Balancing Test}

The majority in Microsoft II also warned against applying more complex "balancing" approaches that would enmesh the court in technical issues and judgments beyond its institutional competence. For example, Judge Wald's separate opinion proposes that Microsoft be allowed to offer an integrated product to OEMs under a single license "only if the integrated product achieves synergies great enough to justify Microsoft's extension of its monopoly to an otherwise distinct market."175 The majority observed, however,

that a balancing test that requires courts to weigh the "synergies" of an integrated product against the "evidence of distinct markets," is not feasible in any predictable or useful way. Courts are ill equipped to evaluate the benefits of high-tech product design, and even could they place such an evaluation on one side of the balance, the strength of the "evidence of distinct markets," proposed for the other side of the scale, seems quite incommensurable. Both Jefferson Parish and Eastman Kodak use their "distinct markets" analysis in a binary fashion: markets are

173 See supra Part IV.B.

174 Microsoft II, 147 F.3d, 935, 952 (D.C. Cir. 1998) (majority opinion).

$175 I d$. at 958 (Wald, J., concurring in part and dissenting in part). One lower court has embraced Judge Wald's dissent in lieu of the majority opinion in Microsoft II. Caldera, Inc. v. Microsoft Corp., $72 \mathrm{~F}$. Supp. 2d 1295, 1323 (D. Utah 1999). For a related criticism of the majority's opinion, see Einer Elhauge, Microsoft Gets an Undeserved Break, N.Y. TIMES, June 29, 1998, at A17.

One might argue that courts in fact enmesh themselves in technical issues all the time, and that it is a normal part of their function to weigh technical issues and make decisions. The mixed success of judicial administration of antitrust decrees in technologically dynamic markets, however, suggests that skepticism is justified. See generally SIDAK \& SPULBER, supra note 115, at 59; Shelanski \& Sidak, supra note 47. 
distinct or they are not. If, as the record suggests, Microsoft proposed modification of the integration proviso because of concern about "vague or subjective criteria," an interpretation requiring courts to weigh evidence that establishes distinctness (or does not) against a sliding scale of net synergistic value looks like the most total transvaluation one can imagine. ${ }^{176}$

My proposed approach is consistent with the majority's rejection of Judge Wald's preferred rule in Microsoft II, for my third step would analyze the likelihood that product integration would preserve monopoly in the tying market, which, in the current generation of government cases against Microsoft, is alleged to be the PC operating system. In other words, my third step would place the burden on the plaintiff of establishing that the product integration would preserve Microsoft's alleged monopoly over operating systems; the focus would not be, as in Judge Wald's preferred approach, on "extension of . . . monopoly to an otherwise distinct market."177 In this respect, my approach is responsive, while Judge Wald's is not, to the theoretical concerns about preservation of monopoly through product integration. ${ }^{178}$ My approach also is responsive, while Judge Wald's is not, to Professor Lessig's related concern regarding the tying of partial substitutes through software integration, which I will address in Part VI.

A further shortcoming of the balancing test proposed by Judge Wald is that it overlooks an intrinsic fact about product integration. The D.C. Circuit warned that it would be asked to make decisions that it had no institutional competence to resolve:

By its very nature "integration" represents a change from a state of affairs in which products were separate, to one in which they are no longer. By focusing on the historical fact of separate provision, the separate opinion puts a thumb on the scale and requires Microsoft to counterbalance with evidence courts are not equipped to evaluate. We do not think that this makes sense in terms of the text of the consent decree, the evidence of the parties' intents, the values the decree was presumably intended to promote, or the competence of the judiciary. ${ }^{179}$

There is no evident reason why these insights of the D.C. Circuit in Microsoft $I I$ concerning the nature of product integration and a court's

176 Microsoft $I I, 147$ F.3d at 952-53 (citations omitted).

177 Id. at 958 (Wald, J., concurring in part and dissenting in part) (emphasis added).

178 See supra Part II.B.2.

179 Microsoft $/ 1,147$ F.3d at 953. For further analysis of the limitations of a court's institutional competence in such matters, see John E. Lopatka \& William H. Page, Antitrust on Internet Time: Microsoft and the Law and Economics of Exclusion, 7 SUP. CT. ECON. REV. 157 (1999). 
institutional competence in matters of software design would not apply equally to a subsequent software tying case arising under $\S 1$ of the Sherman Act.

\section{F. Summation}

With its pronounced consumer-welfare orientation and reliance on economic analysis, the D.C. Circuit's test in Microsoft II is consistent with the approach that I proposed in Part IV for judging the lawfulness of software integration as a matter of tying doctrine under $\S 1$ of the Sherman Act. Microsoft II supplies the intellectual foundation for formally extending to software integration a more deferential antitrust rule for product integration than the courts have traditionally applied to tying arrangements in technologically mature markets. That refinement in antitrust theory is sound and should be recognized as an insight of general applicability rather than as the unique outcome of the interpretation of an isolated consent decree. To aid in that recognition, I have shown that the Microsoft II fits comfortably within the rule that I proposed in Part IV for antitrust scrutiny of software integration.

\section{Judge Jackson's 1999 Findings of Fact Concerning Microsoft's Integration of Internet Explorer and Windows 98}

On May 18, 1998, the Department of Justice and, separately, a group of twenty states and the District of Columbia filed civil lawsuits against Microsoft asserting multiple violations of federal antitrust laws. ${ }^{180}$ Judge Jackson concluded that the cases were substantially similar and ordered them consolidated. ${ }^{181}$ For brevity, and because of the fundamental similarity of the two complaints, I will collectively call the plaintiffs "the Government." The Government made numerous claims, under both $\S \S 1$ and 2 of the Sherman Act, that Microsoft purposefully engaged in a series of actions that were

180 Complaint, United States v. Microsoft Corp., (D.D.C. 1999) (No. 98-1232) [hereinafter DOJ Microsoft Complaint]; Complaint, State of New York ex. rel. Vacco v. Microsoft Corp., (D.D.C. May 18, 1999) (No. 98-1233). The states and the District of Columbia also alleged violations of state antitrust statutes. The states submitted a revised complaint on July 17, 1999. Complaint, State of New York ex. rel. Vacco v. Microsoft Corp., (D.D.C. July 17, 1999) (No. 98-1233). The states participating in the July 17, 1999 complaint were: Califomia, Connecticut, the District of Columbia, Florida, Illinois, Iowa, Kansas, Kentucky, Louisiana, Maryland, Massachusetts, Michigan, Minnesota, North Carolina, New Mexico, New York, Ohio, South Carolina, Utah, West Virginia, and Wisconsin. On December 7, 1999, South Carolina withdrew from the states' case.

181 United States v. Microsoft Corp., Nos. 98-1232, 98-1233, slip op. at 1-2 (filed D.D.C. May 22,1998 ). In a subsequent order denying in the main Microsoft's motion for summary judgment, Judge Jackson explained that "[t]he complaints allege essentially the same antitrust violations" and "seek virtually the same relief." United States v. Microsoft Corp., 1998-2 Trade Cas. (CCH) I 72,261 (D.D.C. 1998). 
designed to preserve a monopoly in the personal computer operating system market and to extend that monopoly to the Internet browser market. 182

On November 5, 1999, Judge Jackson issued lengthy findings of fact that overwhelmingly accepted the Government's factual allegations against Microsoft. Judge Jackson found that Intel-compatible PC operating systems constituted a relevant market and that Microsoft held monopoly power in this market. ${ }^{183} \mathrm{He}$ also agreed with the bulk of the Government's contentions regarding Microsoft's actions over the past decade. Most significantly for assessing Microsoft's legal liability, he concluded that these actions "could only have been advantageous if they operated to reinforce monopoly power,"184 and that while they bestowed some benefits on consumers, in the main these actions harmed consumers by inhibiting competition and innovation in the computer industry. 185 Because of the expanse of Judge Jackson's total findings of fact, I address here only those findings concerning Microsoft's integration of Internet Explorer and Windows 98 that are relevant to whether Microsoft engaged in unlawful tying in violation of $\S 1$ of the Sherman Act. 186

\section{A. Middleware Threats to Microsoft's Operating System Monopoly}

Judge Jackson concluded, consistently with the Government's contentions, that beginning in the spring of 1995 Microsoft perceived the emergence of cross-platform middleware, particularly Netscape's Navigator browser, as a threat to its monopoly power. ${ }^{187}$ Judge Jackson found that Microsoft had also identified other cross-platform middleware technologies as threats, namely IBM's Notes software, Apple's Quicktime software, RealNetworks' multimedia playback technologies, and Intel's Native Signal Processing software.188 Judge Jackson asserted, however, that Navigator

182 DOJ Microsoft Complaint, supra note 180, ๆศ 1-38, 53-123; State Microsoft Complaint, supra note 180, ๆT 9-78; Plaintiffs' Joint Proposed Conclusions of Law at 1-2, 2-54, 66-70, United States v. Microsoft Corp. (D.D.C. 1999) (Nos. 98-1232, 98-1233) [hereinafter Plaintiffs' Proposed Conclusions of Law].

183 Findings of Fact ๆी 18-66, United States v. Microsoft Corp. (D.D.C. 1999) (Nos. 98-1232, 98-1233) [hereinafter Microsoft Findings of Fact].

184 Id. 167.

185 Id. 1 १ $408-12$.

186 For a summary of Judge Jackson's findings of fact on other antitrust claims, see Shelanski \& Sidak, supra note 47.

187 Microsoft Findings of Fact ๆๆ 68-77. Judge Jackson noted that Microsoft recognized Java as a threat to its monopoly power in the spring of 1996. Id. $\uparrow 75$.

188 Id. T 78. Judge Jackson observed that Intel's Native Signal Processing software, while intended to operate cross-platform, was not a form of middleware because it was designed to interact with a

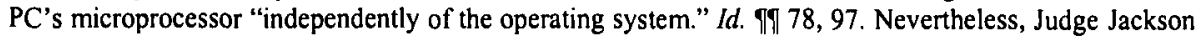
concluded that Microsoft feared this technology for the same reasons that it feared other forms of crossplatform middleware. $I d$. $\{\uparrow 78,94-103$. 
figured most prominently in Microsoft's concerns because it was wellpositioned to serve as a platform for "network-centric applications that run in association with Web pages." 189

Judge Jackson explained that Microsoft feared these technologies because they could run on multiple operating systems (hence the denomination "cross-platform") and because they exposed their own APIs on which software developers could rely in lieu of the APIs exposed in the underlying operating system. Microsoft recognized, Judge Jackson concluded, that if middleware programs became widely used-and simultaneously exposed sufficient numbers of APIs to support the advanced, full-featured applications that run on Windows-then large numbers of software developers would have sufficient incentive to write applications that relied entirely on middleware APIs, and developers and consumers alike would no longer be reliant on Windows as an applications platform. In this manner middleware could, according to Judge Jackson, "dissipate" the positive feedback loop that supports the "applications barrier to entry," thereby erode that barrier, and, in the parlance of Microsoft's worst fears, turn Windows into a commodity. 190

Judge Jackson concluded, consistently with both the Government's contentions and his decision to exclude middleware from the relevant market, that the threat to Microsoft's operating system monopoly posed by middleware technologies was not imminent because these technologies exposed significantly fewer APIs than Windows did, and thus such middleware could not support the full-featured applications that Windows supported. Navigator and Java combined exposed fewer than a thousand APIs while Windows exposed nearly ten thousand.191 Microsoft nevertheless feared these technologies because of the potential threat that they posed. ${ }^{192}$

\section{B. Microsoft's Response to the Browser Threat}

Based on the evidence at trial, Judge Jackson concluded that Microsoft first sought to contain the threat posed by Navigator by seeking Netscape's agreement, in mid-1995, to divide the browser market. ${ }^{193}$ Netscape refused Microsoft's proposal, and thereafter Microsoft delayed the provision of Windows technical information to Netscape. This delay prevented Netscape

\footnotetext{
189 Id. ๆ 69

190 Id. $\Upsilon 68$

191 Id. 977.

192 Id.

193 Id. \$1 79-83. Judge Jackson observed that, at the time of Microsoft's proposal, Navigator was the only browser that enjoyed enough market share to have the potential to erode the applications
} barrier to entry. Id. $\ 89$. 
from releasing the Windows 95 version of its browser until after Microsoft's retail release of Windows 95 and Internet Explorer. ${ }^{194}$

In Judge Jackson's view, Microsoft recognized that, if Navigator emerged "as the standard software employed to browse the Web," then large numbers of developers would write software applications that ran on its APIs and Navigator could thereby erode the applications barrier to entry. ${ }^{195}$ Accordingly, after Netscape refused Microsoft's proposal, Microsoft sought to prevent Navigator from becoming the standard by maximizing Internet Explorer's market share at "Navigator's expense."196 Microsoft accomplished this goal in part by competing on quality and price. Specifically, from 1995 forward, Microsoft spent more than $\$ 100$ million annually to improve the quality of Internet Explorer to the point where industry reviewers were split over whether Internet Explorer or Navigator was the superior product.197 Microsoft also spent $\$ 30$ million annually promoting Internet Explorer. Judge Jackson further found that Microsoft bundled Internet Explorer with Windows 95 and later technically integrated Internet Explorer with Windows 98 and offered Internet Explorer for free. Judge Jackson found that Microsoft did this despite its large investment in Internet Explorer and the potential to obtain significant revenues from its sale. Judge Jackson conceded that Microsoft might have given Internet Explorer away for free to respond to competition rather than to preserve the applications barrier to entry. He concluded, however, that Microsoft's determination to preserve that barrier "was the main force driving its decision to price the product at zero."'198

Judge Jackson determined that, because Navigator's then-existing market penetration had been far ahead of Explorer's, Microsoft had not believed that competition alone would succeed in diverting "enough browser usage from Navigator to neutralize it as a platform."199 Judge Jackson concluded that Microsoft foreclosed the OEM distribution channel to Navigator by prohibiting OEMs from removing Internet Explorer from Windows or from altering or customizing the Windows boot-up sequence. He found that Microsoft enforced these prohibitions, which some large OEMs protested, by leveraging its power in the operating system market and including within its Windows licensing contracts provisions that allowed it to withhold Windows licenses from OEMs that failed to comply.200 Judge

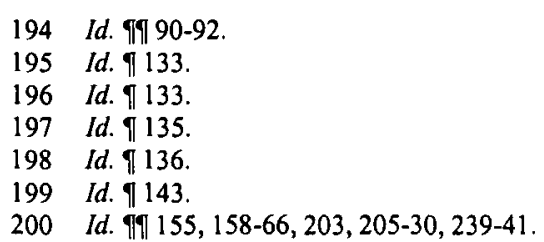


Jackson found that Microsoft reasoned correctly that the restriction against removing Internet Explorer would deter OEMs from loading Navigator onto their PCs because to do so would increase support costs and consumer confusion, to the point where OEMs' profits on the sale of a computer would be depressed.201 In support of his conclusion regarding foreclosure, Judge Jackson noted that by January 1998, only four of sixty OEM sub-channels shipped Navigator with their PCs, and these four did not necessarily place its icon on the desktop, the manner in which customers were most likely to use it.202 Judge Jackson further determined that the restriction against altering the boot-up sequence served to prevent OEMs from (1) featuring Navigator on the Windows desktop more prominently than Internet Explorer, (2) making their PCs more user-friendly, and (3) differentiating their PCs from those sold by their competitors. ${ }^{203}$

Judge Jackson concluded that browsers and operating systems are two separate products because consumers seek to purchase them separately and because there is general agreement within the software industry that the functionalities that these two products provide are distinct. ${ }^{204}$ In support of his conclusion, Judge Jackson observed that some consumers do not want browsers with their operating systems, and that corporate consumers using multiple operating systems may seek to purchase a browser independently of the operating system to ensure the maintenance of uniform browser software across different operating system platforms used within the companies. ${ }^{205}$ Noting Microsoft's argument that other vendors bundle browsers with their operating system, Judge Jackson concluded that Microsoft was the only vendor that did not give OEMs and consumers the choice either not to install the browser or to uninstall it.206 Given the Government's demonstration at trial that Internet Explorer could be removed without harming the functionality of Windows, Judge Jackson concluded that no technical reason existed for Microsoft to prohibit consumers from removing Internet Explorer from Windows. 207

Judge Jackson was not persuaded by Microsoft's arguments regarding the technical virtues of combining Internet Explorer and Windows. He concluded that Microsoft integrated browsing-specific routines with operating system routines "to a greater degree than is necessary to provide

201 See id. 9159

202 Id. ๆ 239.

203 Id. ๆा 205-30, 241

204 ld. ๆ $150-54$.

205 Id. $\ 151$.

206 Id. $\ 155$.

207 Id. IT 175-85. 
any consumer benefit,"208 and that Microsoft thereby "unjustifiably jeopardized the stability and security of the operating system,"209 not only for consumers who wanted a browser, but also for consumers who did not. $\mathrm{He}$ further found that the integration of Internet Explorer and Windows reduced the speed of a PC, a disadvantage for consumers who did not want a browser.210 Finally, Judge Jackson concluded that Microsoft integrated Internet Explorer into Windows not for any procompetitive purpose, but purely to restrict Navigator's distribution and to stop "Navigator from weakening the applications barrier to entry." 211

In judging the impact on the market shares of Internet Explorer and Navigator of Microsoft's restrictions on OEMs, Judge Jackson concluded that Microsoft had significantly increased Internet Explorer's share of the browser market and significantly decreased Navigator's share. Judge Jackson concluded that Navigator's share had decreased from around 70 percent in the beginning of 1996 to around 50 percent in mid-1998, while Internet Explorer's share had increased from around 5 percent to 50 percent by mid1998. He found that some of the increase in Microsoft's market share was due to its improvements in its product and its decision to give it away for free but, nevertheless, concluded that Microsoft's share would not have increased as much as it did if it had "not devoted its monopoly power and monopoly profits to precisely that end."212

In assessing Microsoft's intent, Judge Jackson concluded that while Microsoft might have given Internet Explorer away for free to consumers and expended millions of dollars in developing and promoting Internet Explorer to respond to competition, Microsoft would not have sacrificed the millions of dollars in revenues that it could have obtained by charging other vendors for Internet Explorer and by charging for spots on the Windows desktop, 213 and spent the millions of dollars that it did in securing for Internet Explorer the most efficient distribution channels, unless Microsoft perceived "browser usage share as the key to preserving the applications barrier to entry."214 Judge Jackson concluded that Microsoft's actions were profitable only to the extent that they preserved the applications barrier to entry. ${ }^{215} \mathrm{He}$ found that Microsoft did not act to maximize the ancillary revenues it could have derived from the sale of Internet Explorer. Even if Microsoft had acted

\begin{tabular}{|c|c|}
\hline 208 & Id. $\$ 174$. \\
\hline 209 & $I d$ \\
\hline 210 & Id. $\ 173$. \\
\hline 211 & Id. गี 155. \\
\hline 212 & Id. 9358 \\
\hline 213 & Id. ๆึ 138-42. \\
\hline 214 & Id. 1141 \\
\hline 215 & Id. ๆึ 138-42. \\
\hline
\end{tabular}


in this regard, however, Judge Jackson found that the "ancillary revenue ... realized would not come close to recouping the cost of its campaign to maximize Internet Explorer's usage share at Navigator's expense."216

In Part VII, I will examine the strengths and weaknesses of using Professor Lessig's proposed software integration rule to determine, on the basis of Judge Jackson's findings of fact, whether Microsoft engaged in unlawful tying of Internet Explorer and Windows 98.

\section{Professor Lessig's Proposed Software Integration Rule}

In the 1999 trial of United States v. Microsoft Corporation, the Government argued that Microsoft II was the incorrect standard to apply to Microsoft's integration of Internet Explorer and Windows 98. Professor Franklin Fisher criticized Microsoft II in his direct testimony for the Government: "If combining two products in a way that produces plausible efficiencies (however slight), or that makes it difficult to separate the products, were an absolute defense to a claim that the combination was anticompetitive, software commerce would be essentially immune from tying scrutiny." 217 Professor Fisher believed that "the anti-competitive effects are large" and "the technological benefits appear to be small or non-existent."218 He reiterated that concern in February 2000, stating that if Microsoft II "were to be extended to antitrust law generally, it would provide an open invitation for firms to cloak exclusionary acts in minor innovations." 19 Instead, Professor Fisher argued, Microsoft should be required to offer consumers and OEMs the option to purchase the Internet Explorer Web browser and the Windows 98 operating system separately. By failing to give consumers this alternative, he claimed, Microsoft's actions "had an immediate harmful effect on consumers, ... who faced a limited browser choice ... [and an] unnecessarily cumbersome operating system."220 Nonetheless, Professor Fisher did seem to acknowledge that plausible consumer benefits from the integration of software will be commonly observed. He conceded that "[v]irtually every product design, particularly in the area of computer

216 Id. 7142.

217 Fisher Direct Testimony, supra note 42, I 158. Strictly speaking, Professor Fisher is not necessarily at odds with Microsoft II because the quoted language from his trial testimony is not an accurate summary of the D.C. Circuit's product integration rule. The D.C. Circuit's test asks not only whether plausible consumer benefits flow from the product integration, but also whether consumers are themselves capable of performing the integration of functionalities. See supra Part V.D. By characterizing the rule of Microsoft II as "an absolute defense" to claims of anticompetitive integration of software, Professor Fisher was knocking down a straw man

218 Fisher Direct Testimony, supra note 42, 1158.

219 Fisher \& Rubinfeld, supra note 43, at 51.

220 Id. at 23 
software, can make a plausible claim for some efficiency or benefit,"221 particularly when software products are combined to share code.222

Given this direct attack by the Government on the applicability of Microsoft II to the facts of the 1999 monopolization trial of Microsoft, Judge Jackson requested Professor Lawrence Lessig to submit an amicus curiae post-trial brief addressing the question of "how the law of tying applies to an alleged tie of software products."223 Professor Lessig's brief is especially important to evaluate. As Part VIII will explain, Judge Jackson wrote his findings of law on the tying issue in a way that ensured a collision with the D.C. Circuit's decision in Microsoft II. Afterward, Judge Jackson commented fatalistically in public that "virtually everything" he did in the case "may be vulnerable on appeal" and suggested that he would recuse himself from the case if it were remanded by a higher court. ${ }^{224}$ Thus, as the case moved to the Court of Appeals for oral argument in early 2001, it became more plausible that the tying rule ultimately applied in the Microsoft case would not be the one that Judge Jackson had used. One alternative rule is Professor Lessig's, which Judge Jackson cited approvingly in dicta, as I shall discuss in Part VIII.225

Professor Lessig agreed with most commentators and lower courts that the Supreme Court's tying test in Jefferson Parish is ill-suited for the special facts related to computer software. 226 That point of departure is, of course, also consistent with the rule that I proposed in Part IV. The differences between the products and services at issue in Jefferson Parish and Eastman Kodak on the one hand and computer software on the other, and the perverse results that could arise from an uncritical application of the "consumer demand" test to software, lead Professor Lessig to conclude that "the law in this area is unsettled."227 Again, I agree. Beyond that point, however, I believe that Professor Lessig's rule would have serious shortcomings if it were applied as it now stands because it lacks the kind of economic clarification that I have proposed for a tying rule in Part IV.

221 Id. at 26.

222 Id.

223 Lessig Amicus Brief, supra note 4, at 1.

224 Trial Judge Comments on Microsoft Ruling, N.Y. TIMES, Oct. 28, 2000, at 14C; Microsoft Judge Says He May Step Down From Case On Appeal, Wall St. J., Oct. 30, 2000, at B4.

225 Microsoft Findings of Law, supra note 5, at 51 n.6.

226 Lessig Amicus Brief, supra note 4, at 1.

227 Id. 


\section{A. Professor Lessig's Application of Microsoft II and Jefferson Parish to the 1999 Findings of Fact in the Microsoft Case}

Professor Lessig's brief acknowledged that Judge Jackson could well view the analytical framework articulated by the Court of Appeals in Microsoft II as the controlling standard "in spirit if not in form."228 Judge Jackson himself had made clear that, although the D.C. Circuit's decision "was ostensibly limited to interpreting the specific terms of the Consent Decree, the analysis was, in the Court of Appeals' eyes, 'consistent with tying law."'229 If Microsoft II controls, Professor Lessig plainly stated, then Internet Explorer and Windows 98 are a single product.230

Professor Lessig next considered the outcome if Jefferson Parish's separate demand test is applied without modification to software products. If the existence of separate markets for operating systems and browsers is the only relevant criterion, as Professor Lessig believed it would be under Jefferson Parish, then Windows 98 and Internet Explorer are separate products even in their integrated form. ${ }^{231}$ Professor Lessig expressly agreed with Microsoft, however, that Jefferson Parish's separate demand test is not only inadequate for evaluating software tying claims, but also potentially harmful to consumers:

The concern is over-inclusiveness - that the "separate demand" test in the context of software will condemn far too many bundles, especially if the rule is a "per se" rule. As Microsoft argues, the evolution of software is a constant process of bundling new functionality into old products. As the government acknowledged in the 1994 Tunney Act proceedings, often this bundling involves adding functionality to an operating system that results in the lessening of demand for some software product .... Yet the "separate demand" test places a constant pressure on this bundling. ${ }^{232}$

The Areeda antitrust treatise-now edited by Professor Herbert Hovenkamp following Professor Areeda's death-also agrees that the separate demand test is both inadequate and potentially harmful: "It bears . . emphasis that tying law's 'separate product' requirement was not developed with a product such as computer software in mind." 233 Moreover, if the separate demand

228 Id. at 12.

229 United States v. Microsoft Corp., 1998-2 Trade Cases (CCH) ๆ 72,261 (D.D.C. 1998) (order denying summary judgment) (quoting Microsoft $I I, 147$ F.3d at 950 n.14).

230 Lessig Amicus Brief, supra note 4, at 1, 12-17.

231 Id. at 23-24

232 Id. at 24 (citing 59 Fed. Reg. 59,426, 59,428 (1994)).

233 AREEDA \& HOVENKAMP 1999 SUPPLEMENT, supra note 114, ๆ 1746.1d (quoted in Lessig Amicus Brief, supra note 4, at 24). 
standard is to be the only test, then "virtually all improvements to software would have to be regarded as separate products." 234 This concern, Professor Lessig observed, has led Professor Hovenkamp to propose in the 1999 supplement to the Areeda treatise a new test, specifically intended for software products and written to avoid overinclusiveness, that closely resembles the D.C. Circuit's test in Microsoft II:

[A] single product conclusion seems to be the correct one in all cases in which the code for the two programs is interspersed such that the purchaser cannot readily separate them. The disadvantage of such a rule is that any software producer can comply with it by interspersing code. But the disadvantage of an alternative rule forcing separation is that most of the advantages of integration will have been lost. 235

Because of his concern that there exists a substantial risk that competition and innovation could be stifled rather than fostered by traditional tying tests, Professor Lessig urged Judge Jackson to extend the analysis of Jefferson Parish so that the separate demand test, as it applies to software, weeds out only those bundles that are truly anticompetitive. 236

\section{B. Professor Lessig's Proposed Rule}

Rather than embrace the rule of Microsoft II or of the 1999 Areeda supplement, Professor Lessig proposed his own standard based partly on the 1996 Areeda treatise framework for analyzing tying claims and partly on the facts of the 1999 Microsoft trial. Unlike the 1999 Areeda supplement rule or Microsoft II, Professor Lessig focuses on the combining of functionalities rather than the interspersing of code. He argues that code can be used better than other technologies to hide strategic bundling, and that any legal test should be neutral between contract-based and code-based restrictions on bundling. He intends by his approach to ensure that

[i]f there are two software products that could be combined to operate together "in a new way," then so long as there is no risk of strategic bundling, the law should allow the innovator to decide how the two product are more efficiently combined. The aim of any antitrust inquiry should be whether the particular bundle is a strategic bundle, aiming at

234 Id. $\$ 1746.1$ (quoted in Lessig Amicus Brief, supra note 4, at 24).

235 Id. $11746.1 \mathrm{~b}$.

236 Lessig Amicus Brief, supra note 4, at 22-26, 32. 
anticompetitive ends, not whether the bundle achieves its interlinkage through contract or software. ${ }^{237}$

In identifying whether two separate products have been combined, moreover, the court would consider the nature of the underlying products in terms of functionality rather than as lines of code. A software item should be treated as a separate product if the software functionality is "separately valued by consumers." 238 Applying these criteria, Professor Lessig argues that browser functionality currently is considered a separate product by consumers, but that Microsoft's consolidation of its browser with its operating system should be treated presumptively as a single product under antitrust tying law, "unless an independent reason exists why this type of bundle raises special anticompetitive concerns."239

One such anticompetitive concern in Professor Lessig's schema that could rebut the single-product presumption is if the two functionalities are partial substitutes for one another. If the products are partial substitutes for one another, and if the software vendor combining them has market power in the tying product, then, reasons Professor Lessig, their integration could prohibit the tied product from becoming a competitive substitute for the tying product and thereby engender a specific competitive harm. ${ }^{240}$ Professor Lessig thus addresses the theoretical concerns that software integration could preserve monopoly power over the tying product (operating system software). In Professor Lessig's view, Internet browsers are partial substitutes for the Windows 98 operating system; he therefore argues that the presumption that the Internet Explorer Web browser and the Windows 98 operating system are a single product could be rebutted.241 At the same time, however, Professor Lessig argues that an Internet browser bundled with an operating system could nonetheless be treated as a single product under tying law if the software is configured so as to give consumers an option to refuse the partial substitute. ${ }^{242}$ Thus, even if a Web browser is a partial substitute for the Windows 98 operating system, Professor Lessig still treats the package as a single product if Internet Explorer can be easily removed by the customer without disabling the operating system.

Professor Lessig seems most concerned not that Microsoft has combined a Web browser with Windows 98 , but that the most recent version of Windows 98 had integrated them so that one will not run without the

237 Id. at 39 (emphasis added)

238 Id. at 20.

239 Id. at 40.

240 Id. at 40 (citing 10 AREEDA, Elhauge \& HovenKAMP, supra note 113, \ 1747).

241 Id. at $40-42,43$.

242 Id. at 42. 
other. ${ }^{243} \mathrm{He}$ emphasizes that many of Microsoft's competitors bundle their operating systems with browsers, that this is standard industry practice, and that there is nothing anticompetitive about it.244 Indeed, he acknowledges, combining the two functionalities offers many benefits. ${ }^{245}$ The salient difference for Professor Lessig is that these competitors have not required consumers to take the bundle, and in fact they simultaneously offer their operating systems for sale either without a browser or in a manner that permits the consumer to remove the browser. 246

\section{The Limitations of Professor Lessig's Rule}

Although helpful and constructive in many ways, Professor Lessig's proposed rule for software integration has a number of serious shortcomings. These shortcoming make Professor Lessig's rule less appropriate for courts to adopt than the rule of Microsoft II, as refined by the analysis that I set forth in Part IV.

\section{Integrated Functionalities and Strategic Code Writing}

First, Professor Lessig's focus on a software product's "functionalities" is potentially more misleading than the "strategic" code writing that he seeks to discourage. What may appear to one person to be strategic code writing will appear to another to be superior efficiency. The integration of functionalities through shared code is, by definition, an economy of scope. Code sharing among the Internet Explorer Web browser and the Windows 98 operating system can economize on development costs, not only for Microsoft, but also for other firms that produce applications software that runs on the Windows platform. This savings in development costs arises because the applications software need not duplicate certain lines of code. Such elimination of duplicative code also economizes on the use of disk space on the consumer's hard drive. Although some may regard that savings in information storage as insignificant today, it need not be in the future, as applications software continues to proliferate. For these reasons, code sharing embodies cost subadditivity. ${ }^{247}$

243 See id. at $41-42$.

244 Id. at $30-31,42$.

245 Id. at 3.

246 Id. at 30, 42 (citing Innovation Data Processing v. Int'l Bus. Machs. Corp., 585 F. Supp. 1470,1476 (D.N.J. 1984)).

247 Business and computer industry publications praised the integration features of Windows 98 , although those assessments do not necessarily refer specifically to cost of development or size of code benefits. See, e.g., Stephen H. Wildstrom, Why I'm Rooting for Microsoft, Bus. WK., Feb. 23, 1998, at 30 
Moreover, the "functionality" to which Professor Lessig refers is really Web browsing only, whereas Internet Explorer in fact provides other functions that support both the operating systems and the applications. That is why in Windows 98 it is not possible to disable totally and remove Internet Explorer without also disabling Windows.

It therefore is more complex than Professor Lessig suggests to define exactly what is meant by a "functionality" without reference to the underlying system architecture. It would therefore be likely that courts seeking to define the relevant "functionalities" of a given software package under Professor Lessig's proposed rule would be drawn into the detailed inquiries about product design that the D.C. Circuit in Microsoft II regarded itself as lacking the institutional competence to undertake.

\section{The Tied Product as a Partial Substitute for the Tying Product}

A second difficulty with Professor Lessig's analysis is his view that it is necessarily anticompetitive for software products that are partial substitutes to be combined and that this factor is enough to overcome the presumption that an integrated product should not be treated as two separate products under anti-tying law. At the outset, one must ask whether or not Professor Lessig intends to use the economic concept of a substitute in a technical economic sense. Regardless of whether he does or does not, problems arise with his analysis, though for different reasons.

\section{a. Taking Partial Substitutes Seriously}

Let us assume that Professor Lessig intends to present an argument grounded in economic theory. What, then, is a "partial" substitute, how does it differ from a "total" substitute, and how would one measure the difference? Professor Lessig's explication of his model of partial substitutes answers none of these questions and, to the best of my knowledge, the concept of a "partial substitute" is not defined in any of the major texts on microeconomic theory or industrial organization. ${ }^{248}$ The discussion of partial

("[T]he incorporation of browsing and other Internet function into Windows is a powerful innovation. It may be very inconvenient for Microsoft's competitors, but it's a big gain for consumers, who should be allowed to enjoy those benefits.").

248 A definition of "partial substitutes" cannot be found in any of the following leading texts on microeconomic theory or industrial organization: WILLIAM J. BAUMOL, ECONOMIC THEORY AND Operations analysis (3d ed. 1972); DENNIS W. Carlton \& JefFrey M. PERloff, MOdERN INDUSTRIAL ORGANIZATION (2d ed. 1994); HANDBOOK OF INDUSTRIAL ORGANIZATION (Richard Schmalensee \& Robert D. Willig eds., 1989); JAMES A. HENDERSON \& RICHARD E. QUANDT, MiCROECONOMIC THEORY: A MATHEMATICAL APPROACH (3d ed. 1980); MICHAEL D. INTRILLIGATOR, Mathematical OPTIMIZATION AND ECONOMIC THEORY (1971); DAVID M. KREPS, A COURSE IN 
substitutes in Professor Hovenkamp's supplement to the Areeda treatise (from which Professor Lessig draws his own analysis) is not any more rigorous in economic terms. 249

In price theory, any good $X$ has complements and substitutes. A complement is a good $Y$ whose demand increases as the price of good $X$ falls. Economists quantify the complementarity between goods $X$ and $Y$ through the cross-price elasticity of demand for $Y$ with respect to $X$. If the demand for $Y$ increases as the price of $X$ falls, then the cross-price elasticity of demand for $Y$ with respect to $X$ is a negative number and $Y$ is a complement of $X .250$

Conversely, a substitute is a good $Z$ whose demand increases as the price of good $X$ rises. Again, the cross-price elasticity of demand is price theory's standard metric. If the demand for $Z$ increases as the price of $X$ rises, then the cross-price elasticity of demand for $Z$ with respect to $X$ is a positive number and $Z$ is a substitute of $X .251$

What might it mean for a good to be a "partial" substitute of another good? Can the tied good "partly" substitute for the tying good and, simultaneously, "partly" serve as a complement to it? Might the cross-price elasticity of demand sometimes be positive and sometimes be negative?252 The subtleties of complementarity and substitution have fascinated the minds of Nobel laureates. In 1947, for example, Professor Paul Samuelson wrote: "There is no reason why two distinct definitions [of complementarity] should give the same answer in any particular case, so it is not surprising that one can invent examples ad infinitum for which two goods, such as wheat and linen, are on one of the definitions complements and on the other substitutes."253 Surely, it is too intellectually sloppy for a court to outlaw

MiCROECONOMIC THEORY (1990); LOUIS PHLIPS, APPLIED CONSUMPTION ANALYSIS (1974); ROBERT S. PINDYCK \& DANIEL L. RUBinfELD, MiCROECONOMICS (2d ed. 1992); F.M. SCHERER \& DAVID ROSS, INDUSTRIAL MARKet STRUCTURE AND ECONOMIC PERForMANCE (3d ed. 1990); GeORGE J. STIGLeR, THE THEORY OF PRICE (4th ed. 1987); JEAN TIROLE, THE THEORY OF INDUSTRIAL ORGanization (1988); VARIAN, supra note 10.

249 See AREEDA \& HOVENKAMP 1999 SUPPLEMENT, supra note 114, 1 1746.1d.

250 E.g., KREPS, supra note 248 , at 61.

251 Id.

252 Depending on whether or not compensating variations in income keep the consumer on the same indifference curve, "it is possible for a pair of goods to be substitutes in terms of [the cross-price substitution effect], and at the same time to be gross complements." HENDERSON \& QUANDT, supra note 248, at 32. This outcome would be a quirk of the income effect, which is sometimes omitted when economists loosely speak of substitutes and complements. E.g., BAUMOL, supra note 248, at 363 . One cannot determine from Professor Lessig's brief, or from the authorities which he cites, whether his theory of partial substitutes bears any relationship to the formal theory of gross substitutes and gross complements, such as it is presented in the standard microeconomics text of Professors Henderson and Quandt.

253 Paul A. Samuelson, Foundations of Economic Analysis 185 (1947). Following the terminology of Sir John Hicks, Professor Samuelson uses the term independent goods to describe a pair of products, "such as beef and textbooks, for which a price change for one good has no effect on the demand for the other." PAUL A. SAMUELSON \& WILLIAM D. NORDHAUS, ECONOMICS 81 (15th ed. 1995); see also 
certain practices concerning the integration of software used by millions of consumers on the basis of imprecise and empirically unsubstantiated conjectures about the cross-price elasticity of demand of Internet Explorer with respect to Windows 98 .

Perhaps Professor Lessig envisions that the total cross-price elasticity of demand for Internet Explorer with respect to Windows 98 can be decomposed into two "partial" components of demand. The first would be the summation of consumer demand for which Internet Explorer (or a nonMicrosoft Web browser) is a complement to Windows 98 . The second would be the summation of demand among the remaining set of consumers for whom Internet Explorer (or a non-Microsoft Web browser) is a substitute for Windows 98. In such a functional specification of demand, one would need to sum the complementarity and substitution effects to evaluate whether, on balance, Internet Explorer is a net complement to or a net substitute for Windows 98.

Such an exercise would, of course, require empirical estimates of the cross-price elasticity of demand (by customer segment). It is not sufficient to say that, for some customers, the demand for Navigator would rise with an increase in the price of Windows 98 , and vice versa. ${ }^{254} \mathrm{~A}$ cross-price elasticity of 0.05 would not support the same inferences about the consumer welfare effects of allegedly anticompetitive software integration as would a cross-price elasticity of 1.00 . Which magnitude is closer to the true crossprice elasticity of non-Microsoft Web browsers with respect to Windows 98 (assuming for the sake of argument that the sign on the elasticity is positive)? Professor Lessig's approach avoids this empirical question entirely by implicitly treating cross-price elasticity as a binary variable (two goods either are substitutes or they are not) rather than as the continuous variable that it is. By so doing, Professor Lessig's approach omits many analytical steps that would be necessary before a court could reliably conclude that nonMicrosoft Web browsers and the Windows 98 operating system were sufficiently cross-price elastic that harm to consumer welfare could result from Microsoft's integration of Internet Explorer and Windows 98.

Of course, neither Professor Lessig nor any of the government's witnesses in the Microsoft trial endeavored to estimate such demand relationships empirically. At a minimum, therefore, one must say that the

\footnotetext{
PHLIPS, supra note 248, at 78 (discussing JOHN R. HICKS, VALUE AND CAPITAL (1936)). It is not clear how independent goods fit into Professor Lessig's theory of partial substitutes, if at all.

254 Moreover, it is not the case that the cross-price elasticity of demand of $X$ with respect to $Y$ is equal to the cross-price elasticity of $Y$ with respect to $X$. This caveat is especially important for antitrust policy in technologically dynamic industries. See Jerry A. Hausman, J. Gregory Sidak \& Hal J. Singer, Residential Demand for Broadband Telecommunications: Implications of Cable Mergers for Consumer Access to Unaffiliated Internet Content Providers, 18 YALE J. ON REG. (forthcoming 2001).
} 
conjecture that the combining of "partial substitutes" constitutes an anticompetitive form of product integration is an inherently factual proposition which, to be taken seriously, would require the government to submit econometric evidence of the consumer demand for both the Windows 98 operating system and the Web browsers that supposedly provide the basis for creating rival applications platforms. The record of the Microsoft trial provided no basis for making economically informed judgments on this question.

\section{b. Partial Substitutes as a Metaphor}

I regard the notion of partial substitutes to be useless unless it can be expressed with some modicum of economic rigor that would ensure neutrality and predictability in the application of the concept. Some might respond, however, that the problem is mine-that I am misreading Professor Lessig. The argument would be the following: Professor Lessig is not using partial substitute in a technical economic sense at all. The Microsoft case all along has concerned the notion that the browser has certain aspects that are complementary to the operating system (as any application has) and other aspects that are potential substitutes, such that the browser could migrate into being a platform itself. As a descriptive matter, everyone would agree that the browser could replace (that is, "substitute for") Windows. If one replaces that wordy explanation with the short-hand expression "partial substitute," no one familiar with the facts of the Microsoft case would disagree. In that sense, Professor Lessig's invocation of partial substitutes has nothing to do with cross-price elasticities.

Even with this alternative reading of Professor Lessig, there are at least two problems that severely limit the usefulness of partial substitutes as a label or metaphor to be used in antitrust law. First, the Microsoft case is by any standard a case of extraordinary factual complexity. Few persons, even including the appellate judges who will decide the case, can be expected to steep themselves in all of the case's institutional detail. If the concept of partial substitutes is employed to decide the case, that concept will acquire a life of its own, wholly divorced from the intimate factual understanding of those directly involved in the Microsoft litigation. That is so because of the importance of the Microsoft case, because of the substantial reputation of the scholar proposing this nomenclature, and because the malleability of the concept of partial substitute-if it is not constrained by precise economic reasoning-will invite other litigants in other cases to give the concept a meaning that suits their immediate purposes. One need only examine the 
growth in reported claims of violation of the essential facilities doctrine to be reminded how much case law a catchy slogan can generate. ${ }^{255}$

A second, perhaps more substantive, difficulty that arises when "partial substitute" is employed at the level of label or metaphor is that it obscures the idea that antitrust law should, as Professors Daniel Kessler and William Baxter argue, ${ }^{256}$ treat conduct or agreements concerning complements differently from conduct or agreements concerning substitutes. Automobiles are complements to airlines for traveling between downtown London and downtown Paris, by way of Heathrow and De Gaulle Airports. But one might say automobiles are also partial substitutes for airlines for the intercity portion of that journey, because the Channel Tunnel permits an automobile to travel by railroad flatcar underneath the English Channel. For however long browsers remain complements to Windows, antitrust law should give greater deference to conduct or agreements that integrate the two functionalities. When, because of technological change or changes in consumer tastes, browsers have become substitutes for Windows, antitrust law should give lesser deference to such product integration. To speak ambiguously of "partial" substitutes is to truncate or eliminate entirely the earlier period of antitrust deference that should appropriately be given to product integration among complements.

3. Substitutability and Market Definition: Intel-compatible PC Operating Systems versus Applications Platforms

A third problem with Professor Lessig's notion of partial substitutes (and, indeed, with his approach generally) is that it calls into question the logic of defining the relevant market, for purposes of evaluating Microsoft's market power, as the market for Intel-compatible PC operating systems. To say that Web browsers can substitute for Windows 98 in the sense that they make possible the establishment of rival applications platforms is to say that the relevant product market should be defined to encompass all applications platforms, not simply Intel-compatible PC operating systems. Under such a market definition, however, all inferences about Microsoft's market power would have been attenuated. In a sense, therefore, Professor Lessig's theory of partial substitutes is an example of having one's cake and eating it too: The government can assert a narrowly prescribed relevant product market

255 Abbott B. Lipsky, Jr. \& J. Gregory Sidak, Essential Facilities, 51 STAN. L. REV. 1187 (1999); Philip E. Areeda, Essential Facilities: An Epithet In Need of Limiting Principles, 58 ANTITRUST L.J. 841 (1990).

256 William F. Baxter \& Daniel P. Kessler, Toward a Consistent Theory of the Welfare Analysis of Agreements, 47 STAN. L. REV. 615 (1995). 
and then argue that, as a matter of tying doctrine, the tied product is a thwarted substitute for the tying product, which has been found to embody market power because of the restrictive market definition that excludes the possibility of competition from the tied product.

\section{Real Options and the Oddity of Disabling as an Antidote to Tying}

Fourth, Professor Lessig's analysis has an arbitrary quality that is characteristic of legal fictions. The integration of partial substitutes is suspect in his schema, such that he deems them separate products for purposes of tying doctrine. Yet, if the consumer can disable the tied software, then Professor Lessig excuses the integration. Expiation flows from the disabling of shared code: If the consumer can, at low cost, negate the cost subadditivities of software integration, then two separate products in Professor Lessig's schema will nonetheless be treated, for purposes of imposing liability under accepted tying doctrine, as a lawfully integrated product.

He admits: "It might seem odd to conceive of a tie as constituted by the failure to permit the removal of software product."257 Professor Lessig is correct. It is odd. Two plus disabling equals one. Professor Lessig tries to make tying law's traditional examination of separate products perform an analytical task for which it is ill-suited and uninformative. As noted earlier, the D.C. Circuit refused to do such a thing, stating in Microsoft II that "[a] tie-in is not affected by the purchaser's ability to discard the tied good."258

The fact that both Internet Explorer and Navigator are given away for free, that no OEM or consumer is in any way "forced" to purchase Internet Explorer, and that any OEM or consumer can easily install Navigator if desired also reveals the limitations of Professor Lessig's focus on removability as a remedy for the "partial substitute" phenomenon that he describes. Professor Lessig argues that if Internet Explorer can be easily removed, then no consumer is "forced" to take it.259 In contrast, he argues, "[t]he relevant forcing [in the PC software market] is the refusal to allow the consumer the option to decline the offer." 260 But how is it ever meaningful to say that a consumer has been "forced" to receive for free an extra, convenient feature in a product? Even the consumer who prefers another browser is free at all times to take or leave Internet Explorer, just as the sports fan who subscribes to the Sunday New York Times is free to keep or

257 Lessig Amicus Brief, supra note 4, at 30.

258 Microsoft II, 147 F.3d 935, 941 n.3 (D.C. Cir. 1998); see also supra note 139.

259 Lessig Amicus Brief, supra note 4, at 40-42.

260 Id. at 31 (emphasis added). 
discard the New York Times Review of Books. If the consumer likes Internet Explorer, she uses it; if she prefers Netscape, she simply downloads it from software on the Internet or instructs Dell to install it on her new computer. None of those courses of action is difficult as a practical matter.

Microsoft's product integration gives the consumer a real option in the precise economic sense of the term and a real option plainly confers considerable value to its holder, as is widely understood in the theory of finance. ${ }^{261}$ Any real option subsumes within it what Professor Lessig calls "the option to decline the offer." Perhaps Professor Lessig believes that it is important that a consumer have the prerogative to refuse to receive the offer of a free option. As a matter of economic theory, however, while holding income constant, a consumer's utility cannot be increased by reducing from $n$ to $n-1$ the number of goods that she may consume. Moreover, the cost to the consumer of holding that option is essentially zero because, as Professor Lessig stresses, the capacity of the consumer's hard drive is vast. ${ }^{262}$ It is hard to see that there is any infringement of consumer sovereignty here, let alone one that rises to an antitrust concern. The opacity of Professor Lessig's economic reasoning violates his own warning against turning tying law into "questions of metaphysics." 263

\section{The Revelation of Consumer Demand: Professor Lessig's Price Theory or Professor Knight's?}

Implicit in Professor Lessig's discussion of product integration is an assumption that consumers tell producers how much integration of software is optimal. More generally, one might ask whether it is consumers or producers who decide, in the first instance, which goods producers shall supply. Professor Lessig presumes that consumers make such decisions, and that their evident preference is for less rather than more product integration. In his brief, Professor Lessig asserts: "If it is the purpose of tying doctrine to preserve consumer choice, it would make most sense to view a 'product' as the consumer would."264 From this uncontroversial premise, however, Professor Lessig takes a leap of economic theory, for which he relies on

261 For discussions of real options to use assets that embody sunk costs, see AVINASH K. DIXIT \& ROBERT S. PINDYCK, INVESTMENT UNDER UNCERTAINTY (1994); Hausman \& Sidak, supra note 141, at 462-64; and Jerry Hausman, Valuing the Effect of Regulation on New Services in Telecommunications, 1997 BROOKINGS PAPERS ON ECON. ACTIVITY: MICROECONOMICS 1.

262 Lessig Amicus Brief, supra note 4, at 30-31 ("When a computer is sold, its hard disk is an underutilized shipping container. To the extent it is empty, it represents software that could have been offered to consumers.").

263 Id. at 19.

264 Id at 20. 
Judge Jackson's findings of fact: "Consumers determine their software requirements by identifying the functionalities they desire."265

There is, however, a strong argument about the revelation of consumer demand that Professor Lessig never considers. In 1921, Professor Frank Knight, the great University of Chicago price theorist, argued that producers are better able than consumers to anticipate future consumer preferences. He posed the problem of revelation of consumer preferences as follows: "The essence of organized economic activity is the production by certain persons of goods which will be used to satisfy the wants of other persons. The first question which arises then is, which of these groups in any particular case, producers or consumers, shall do the foreseeing as to the future wants to be satisfied."266 Knight did not believe that consumers specify their preferences clearly to producers. Rather, he reasoned: "At first sight it would appear that the consumer should be in a better position to anticipate his own wants than the producer to anticipate them for him, but we notice at once that this is not what takes place. The primary phase of economic organization is the production of goods for a general market, not upon direct order of the consumer."267

When one considers this insight by Professor Knight in the context of a tying rule for software integration, it becomes increasingly clear that it would be injurious to consumer welfare for a court to condemn the integration of "partial substitutes" unless, as Professor Lessig advocates, the producer allowed consumers to disaggregate the product. To require the producer to do so would thwart the producer's role as the party who facilitates the revelation of consumer preferences. It is reasonable to expect that the importance of this revelation of preferences increases with the extent of technological dynamism in a particular product market. In this respect, the "character of demand" analysis in Jefferson Parish is uninformative when consumers face products for which they have newfound and uncertain demand.

For example, well into the early 1990s, consumers seeking access to the Internet had to install their own software and invest the time to learn how to use it. Web browsing was not yet commonplace. Yet Netscape and Microsoft anticipated the future consumer demand for Internet usage and electronic commerce. Working with OEMs, they offered consumers the convenience of an integrated product consisting of a PC with applications programs and the capability to browse the Internet. The revelation of consumer preferences is a

265 Id. (quoting Microsoft Findings of Fact, supra note 183, ๆ 149).

266 FRANK KNIGHT, RISK, UNCERTAINTY, AND PROFIT 240 (1921).

267 Id. 
genuine innovation or discovery, one whose value courts and antitrust officials can belittle or ignore only at great peril to consumer welfare.

\section{The Comparative Inefficiency of Consumer Bundling of Software}

As noted earlier in the discussion of subadditive costs in Part IV.C, it is doubtful that the consumer is a lower-cost integrator of software functionalities than the software manufacturer. Professor Lessig evidently disagrees: "With software products, whether two items will operate better when bundled by the defendant than when bundled by the customer is simply a matter of software design. If there is a difference in the functionality of the resulting bundle if installed by the consumer, this is because the designer chose to make it that way." 268 This assessment is misguided in at least two respects.

First, it overlooks that when the consumer performs the software integration, it becomes less clear who is to blame if the software application does not perform as intended. If the consumer has not attempted to integrate the software functionalities himself, he has one less potential source of the failure. Only someone who has never had his computer crash would minimize the significance of this consideration. As noted in Part II.A, courts have accommodated this quality-control concern in the law on tie-ins. It would be curious to give that concern so little weight in the context of software integration as Professor Lessig's rule suggests.

Second, Professor Lessig ignores the cost of the labor supplied by the consumer to effect the integration. Professor Lessig believes that fitting cars with bumpers and transmissions is harder than integrating software functionalities, in part because "installing [bumpers and transmissions] properly requires training." 269 And installing software does not? Professor Lessig may be more facile with software than automobiles, but many consumers dislike loading and configuring software onto their personal computers because they regard the task as confusing, time-consuming, poorly documented, or frustrating. Such consumers, unlike the computer enthusiast, do not derive any consumption value from the integration process. Large law firms typically do not ask their associates to load and maintain their own software on their computers. There is a more productive use of associates' time, and other employees have a comparative advantage

268 Lessig Amicus Brief, supra note 4, at 35 (emphasis added).

269 Id. The other reason that Professor Lessig offers for why consumers can more easily integrate software than physical products is cryptic indeed: "bumpers and transmissions are heavy and large objects to handle-not because the manufacturer has made them that way, but because nature has made them that way." Id. (emphasis added). 
in computer maintenance. The rebuttal might be: Continue to require consumer integration, and expect specialized third-party integrators to emerge. But there would still be nontrivial transactions costs. Even when consumer integration does not require specialized knowledge, it may nonetheless be an inefficient use of the consumer's labor. In England appliances are sold without the plug already attached to the end of the electrical cord; the consumer then goes to an electrical store to buy the proper plug given the wiring in his residence. Many Americans would find it bizarre if they were expected to "integrate" the vacuum cleaner and the plug. They value convenience. An hour spend loading one's own software is an hour not spent reading Proust or watching the World Wrestling Federation.

7. Preordaining the Answer: Equating the Separateness of Products with an Anticompetitive Effect of Integration

Professor Lessig's proposed approach starts with a presumption that two software products bundled together are an integrated product, unless the two functionalities combined have an anticompetitive effect. 270 If, in other words, it is a bundle of the kind of products likely to cause an anticompetitive harm, then the presumption finding a 'single product' would be rebutted.271 The fallacy of this reasoning is that it asks an economic question to decide a legal fiction: If anticompetitive effects flow from product integration, then two products are indeed two products; but if no anticompetitive effects flow from product integration, then two products are really only one product. Such logic is untenable.

As shown above, Professor Lessig's notion of partial substitute as a proxy for such an effect suffers from the same defects for which Professor Lessig criticizes Jefferson Parish and the separate demand standard. What, then, is the true "anticompetitive" effect? If the consumer welfare test remains the ultimate standard for the measurement of harm, how has the consumer been harmed? How can providing her with Web-browsing capability for free and a vastly improved and more efficient operating system be said to have harmed her? Even if the consumer prefers another Web browser, what prevents her from using it? Certainly not the added cost of receiving Internet Explorer, for that is zero. 
8. Does the Lawfulness of Product Integration under Professor Lessig's Rule Ultimately Collapse into an Analysis of Predation?

Professor Lessig argues that "[t]he aim of any antitrust inquiry should be whether the particular bundle is a strategic bundle, aiming at anticompetitive ends, not whether the bundle achieves it [sic] interlinkage through contract or software." $272 \mathrm{He}$ would permit a firm to integrate software in a new form, either through contract or through the interspersing of code, "so long as there is no risk of strategic bundling." 273 Zero tolerance, however, is a very demanding standard. If Professor Lessig intends to propose an antitrust rule that tolerates no risk of strategic bundling, it is incumbent upon him to define the concept more specifically than to say simply that a "strategic" bundle is one "aiming at anticompetitive ends."

Every firm has a "strategic" purpose in selecting particular product designs, pricing structures, marketing efforts, and the like. One way to interpret "strategic" is to regard it as the adjective that describes the informed actions of firms that are forced to respond to competitive threats. An efficacious competitive strategy will naturally cause the firms against which it is directed to characterize the strategy as "anticompetitive." Another way to interpret "strategic" is to equate it with "predatory." In Microsoft's case, one can ask whether its integration of Internet Explorer into Windows 98 was a legitimate competitive response to the threat that other companies would create middleware alternatives to the Windows application platform, or whether such integration was an anticompetitive act. To discriminate between the two hypotheses, Professor Lessig suggests that "strategic" code writing is the cost that must be weighed against the putative consumer benefits of software integration. If, however, the ultimate determination of whether particular code is "strategically" written turns on its profitability in the absence of other firms' exiting the market, then the tying rule that Professor Lessig advocates requires, as its final step, a determination that would resemble an entire predatory pricing inquiry.

\section{The Limits of Complex Legal Rules}

A final, overarching weakness of Professor Lessig's approach is the implausibility that it could coherently guide behavior in the real world. "As a matter of judicial policy," he posits, "it is a mistake to fetishize code," and thus he is "not a skeptic of courts' ability to understand how software

272 Id. at 39.

273 Id. (emphasis added). 
functions." 274 More specifically, he asserts that "courts and commentators have little trouble understanding the difference between a description of 'two products' going into a tying inquiry, and the conclusion that these two products are a 'single product' for purposes of antitrust tying law."275 This belief is problematic on two levels.

First, Professor Lessig is writing a rule for the wrong audience. Ultimately, the question when designing a legal rule is not what "courts and commentators" can or cannot understand. To be sure, in the legal academy there are large payoffs to displaying how elegantly one can manipulate symbols, concepts, and language in the formulation of legal rules. So Professor Lessig may not consider it the least bit pedantic to say that "[ $\mathrm{t}] \mathrm{he}$ 'separate product' or 'single product' designation is the conclusion of a legal analysis, not an instance of ordinary language." 276 But for most people, law is not art, and judicial decisions are not grist for literary criticism. Ordinary language matters. If they truly care about increasing economic welfare, courts in antitrust cases should resist the kind of solipsism in legal scholarship that produces rules that can be understood only by cognoscenti who have removed themselves from the gritty world of commerce. An antitrust rule for software integration ultimately will influence the competitive strategies of real companies with real managers who must decide how to invest billions of their shareholders' dollars to develop real products that real consumers will value. Rather than focus on "courts and commentators," the more useful question to ask is, Would a particular antitrust rule for software integration be comprehensible to a classroom of MBA or computer science students intending careers in technologically dynamic industries? If not, the rule is worthless, or worse. After all, who do we expect to be running software companies in the next decade-antitrust lawyers?

Second, even if we do limit our focus to whether "courts and commentators" can articulate and apply complex antitrust rules for software integration, Professor Lessig's own brief is, if anything, evidence that courts and commentators cannot. Professor Lessig argues that even so experienced a jurist as Judge Stephen Williams (himself a former professor) produces a "mistaken" application of the Areeda treatise's proposed rule on software

274 Id. at 2.

275 Id. at 22.

276 Id. Professor Lessig later states: "To say that two 'software products' have been bundled into the same software package is not yet to conclude that they should be considered 'two products' for purposes of antitrust tying law." Id. Perhaps legal scholars and jurists regard this as a subtle distinction, but they should not be surprised if men and women of commerce regard it as gibberish. 
integration in Microsoft II.277 Professor Lessig also notes that the author of the annual supplement to that treatise, Professor Hovenkamp, changed his opinion from one year to the next on whether it was correct for the D.C. Circuit to find in Microsoft II that Windows 95 and Internet Explorer were an integrated product.278 If Judge Williams and Professor Hovenkamp err and vacillate this much over the analysis of software integration in Microsoft II, one must wonder how lesser lights can be expected to fare with the responsibilities that Professor Lessig's rule would impose. And finally, if complex rules for software integration are really so easy for courts to follow, why did Judge Jackson need Professor Lessig to write an amicus brief on the subject in the first place?

\section{Summation}

Professor Lessig proposes that two software items bundled together by code or by contract be presumptively treated as a single product absent an anticompetitive effect. That proposal has promise. But showing such an anticompetitive effect must turn upon actual evidence of harm to consumers, not on whether the new, integrated product made life more difficult for the firm's competitors, an entirely predictable and desirable consequence.279

277 "While the Court relied in its opinion upon the analysis of the Areeda Treatise, its rule is actually more forgiving than the rule announced in the treatise." Id. at 13. "So, again, if one interprets the Court's opinion as applying antitrust law generally, then its interpretation of the Areeda Treatise at least was mistaken." Id. at 14 n. 12 .

278 Id. at 32 ("While the Court of Appeals, using the [new product] rationale [of the Areeda treatise test for whether integrated products are a single product for tying purposes], concluded the text meant that Windows 95 and IE were likely 'integrated,' the 1998 edition of the treatise, applying the same test, agreed with this [federal district] Court that they should likely be considered 'separate products,' and the 1999 edition of the treatise, applying the same test again, agreed with the Court of Appeals, though for different reasons, that they should be considered 'integrated.") (citing PHILLIP E. AREEDA \& HERBERT hovenKamp, ANTITRUST LAW: AN ANALYSIS OF ANTITRUST PRINCIPLES AND THEIR APPLICATION, 7 1746b (Supp. 1998), in comparison with AREEDA \& HovENKAMP 1999 SuPPLEMENT, supra note 114, ๆ 1746.1 b).

279 For a discussion of the difference between consumer welfare and competitor welfare approaches to antitrust and regulatory policy, see Shelanski \& Sidak, supra note 47 ; and Hausman \& Sidak, supra note 141 , at $452-53$. Justice (then Judge) Breyer has described the difference as follows: "'Anticompetitive' [in antitrust law] also has a special meaning: it refers not to actions that merely injure individual competitors, but rather to actions that harm the competitive process, a process that aims to bring consumers the benefits of lower prices, better products, and more efficient production methods." Interface Group, Inc. v. Mass. Port Auth., 816 F.2d 9, 10 (1st Cir. 1987) (citation omitted). Similarly, Chief Judge Posner has written for the Seventh Circuit: "[T]hough there is a sense in which the exclusion of any competitor reduces competition, it is not the sense of competition that is relevant to antitrust law. The policy of competition is designed for the ultimate benefit of consumers rather than of individual competitors, and a consumer has no interest in the preservation of a fixed number of competitors greater than the number required to assure his being able to buy at the competitive price." Marrese v. Am. Acad. of Orthopaedic Surgeons, 706 F.2d 1488, 1497 (7th Cir. 1983); see also Univ. Life Ins. Co. of Am. v. Unimarc Ltd., 699 
Moreover, the purpose of conducting economic analysis of the competitive effects of a particular instance of software integration should not be to contrive an answer to the question of whether one or two products are present. Unfortunately, Professor Lessig's rule suffers from its willingness to perpetuate the legal fictions of tying doctrine.

His rule suffers as well from its failure to answer satisfactorily a number of economic questions that are critical to consumer welfare: When is code "strategic"? What is the precise meaning of a "partial substitute," and how does that meaning square with the restrictive market definition used by the district court in the Microsoft case? By what alchemy can the disabling of software turn two products into one? How can a consumer suffer any coercion when given a free option to use a software product? What is the comparative advantage of producers over consumers in anticipating consumer demand for software functionalities and, later, integrating those functionalities? What happens if the antitrust rule for software integration is so complex as to be unintelligible to the very economic actors whose behavior the rule is intended to influence? Without better answers to such questions, Professor Lessig's rule cannot assure us that it would enhance rather than diminish consumer welfare. 280

\section{Judge Jackson's Software Integration Rule}

On April 3, 2000, Judge Jackson issued conclusions of law in the Government's antitrust trial against Microsoft, which held that Microsoft had violated the antitrust laws on multiple grounds.281 On the question of the integration of Internet Explorer and Windows 98, the judge explicitly rejected the analysis of Microsoft II. In that respect, Judge Jackson produced a legal rule on software integration that, in contrast to my proposed refinement of the Microsoft II analysis in Part IV, threatens consumer welfare in technologically dynamic markets.

F.2d 846, 853 (7th Cir. 1983); Roland Mach. Co. v. Dresser Indus., 749 F.2d 380, 395 (7th Cir. 1984); Product Liab. Ins. Agency v. Crum \& Forster Ins. Cos., 682 F.2d 660, 663-65 (7th Cir. 1982).

280 The preliminary empirical evidence suggests that antitrust enforcement efforts against Microsoft have caused net losses in economic welfare. George Bittlingmayer \& Thomas W. Hazlett, DOS Kapital: Has Antitrust Action Against Microsoft Created Value in the Computer Industry?, 55 J. FIN. ECON. 329 (2000).

281 Microsoft Findings of Law, supra note 5, at 35-57. 


\section{A. Judge Jackson's Deference to Microsoft II in His 1998 Summary Judgment Motion}

Earlier in the Microsoft case, Judge Jackson appeared to acknowledge that Microsoft II was the controlling legal authority on the question of whether Windows 98 and Internet Explorer are separate products for purposes of tying doctrine under $\S 1$ of the Sherman Act. When ruling on Microsoft's motion for summary judgment in 1998, Judge Jackson said that, although Microsoft II "was ostensibly limited to interpreting the specific terms of the Consent Decree, the analysis was, in the Court of Appeals' eyes, "consistent with tying law.'" $282 \mathrm{He}$ observed that Microsoft II "articulate[d] a framework for determining whether an integration amounts to a single product for purposes of evaluating a tying claim."283 In his April 2000 findings of law, however, Judge Jackson repudiated that legal conclusion.

\section{B. Judge Jackson's 2000 Findings of Law}

In his April 2000 findings of law, Judge Jackson concluded, among other things, that "Microsoft . . . violated $\S 1$ of the Sherman Act by unlawfully tying its Web browser to its operating system."284 Judge Jackson agreed with the Government that "Microsoft's combination of Windows and Internet Explorer by contractual and technological artifices constitute unlawful tying to the extent that those actions forced Microsoft's customers and consumers to take Internet Explorer as a condition of obtaining Windows." 285 In reaching that conclusion, Judge Jackson ruled that the applicable precedent for evaluating Microsoft's product bundling was not the D.C. Circuit's 1998 decision in Microsoft II, but rather the Supreme Court's decisions in Eastman Kodak and Jefferson Parish, neither of which specifically concerned product integration in the computer software industry.286 Judge Jackson stated: "The fact that Microsoft ostensibly priced Internet Explorer at zero does not detract from the conclusion that consumers were forced to pay, one way or another, for the browser along with Windows." 287

Judge Jackson began his discussion of tying under $\S 1$ of the Sherman Act by reciting the blackletter, four-part test for an unlawful tie-in, which he

282 United States v. Microsoft Corp., 1998-2 Trade Cases (CCH) \ 72,261 (D.D.C. 1998) (order denying summary judgment) (quoting Microsoft II, 147 F.3d at 950).

283 Id.

284 Microsoft Findings of Law, supra note 5, at 35

285 Id. at 47.

286 Id. at $47-51$.

287 Id. at 50. 
noted had been reaffirmed by the Supreme Court in Eastman Kodak and Jefferson Parish. ${ }^{288}$ He summarized his conclusion that Microsoft had, "by contractual and technological artifices," created an unlawful tie-in by requiring customers "to take Internet Explorer as a condition of obtaining Windows." $289 \mathrm{He}$ then immediately conceded that his conclusion of law was "arguably at variance with a decision of the U.S. Court of Appeals for the D.C. Circuit in a closely related case, and must therefore be explained in some detail." 290

\section{The Rejection of Microsoft II in Favor of Jefferson Parish and Eastman Kodak}

Judge Jackson wrote that, "upon reflection this Court does not believe the D.C. Circuit intended Microsoft II to state a controlling rule of law for purposes of this case,"291 and he considered the applicability of Microsoft II to be circumscribed accordingly. Any hint by the D.C. Circuit that its reasoning applied generally to the antitrust law of tie-ins was, in Judge Jackson's view, "in the strictest sense obiter dicta" and "not formally binding." 292 In a tone that nearly mocked the appellate court, Judge Jackson hastened to add that "both prudence and the deference this Court owes to pronouncements of its own Circuit oblige that it follow in the direction it is pointed until the trail falters." 293

In Judge Jackson's view, the D.C. Circuit's trail immediately faltered. From the outset of his discussion of the applicable antitrust standard for the integration of software, Judge Jackson took so skeptical a view of the D.C. Circuit's "undemanding" rule in Microsoft II as to say that it contradicted the Supreme Court's precedent on point: "The majority opinion in Microsoft II evinces both an extraordinary degree of respect for changes (including 'integration') instigated by designers of technological products, such as software, in the name of product 'improvement,' and a corresponding lack of confidence in the ability of the courts to distinguish between improvements in fact and improvements in name only, made for anticompetitive purposes."294 Echoing Professor Fisher's testimony, Judge Jackson said: "Read literally, the D.C. Circuit's opinion appears to immunize any product

\footnotetext{
288 Id. at 47.

289 Id.

290 Id. Judge Jackson added: "Whether the decisions are indeed inconsistent is not for this Court to say." Id.

291 Id

292 Id.

293 Id. (emphasis added).

294 Id. at 47 (quoting Microsoft II, 147 F.3d at 950).
} 
design (or, at least, software product design) from antitrust scrutiny, irrespective of its effect upon competition, if the software developer can postulate any 'plausible claim' of advantage to its arrangement of code."295 Then, in the most judicially audacious sentence of his findings of law, Judge Jackson said that the D.C. Circuit had misread Jefferson Parish and Eastman Kodak:

This undemanding test appears to this Court to be inconsistent with the pertinent Supreme Court precedents in at least three respects. First, it views the market from the defendant's perspective, or, more precisely, as the defendant would like to have the market viewed. Second, it ignores reality: The claim of advantage need only be plausible; it need not be proved. Third, it dispenses with any balancing of the hypothetical advantages against any anticompetitive effects. 296

Judge Jackson considered Microsoft II to conflict fundamentally with the Supreme Court's separate-demand analysis in Jefferson Parish and Eastman Kodak.297

In both Jefferson Parish and Eastman Kodak, Judge Jackson observed, the defendants argued that the allegedly tied and tying products "were in reality only a single product, or that every item was traded in a single market." 298 As noted in Part IV, the allegedly tied and tying products were, in Jefferson Parish, hospital services and anesthesiology services 299 and, in Eastman Kodak, replacement parts for Kodak photocopying and micrographic equipment and repair services for such equipment. ${ }^{300}$ This single-product argument, Judge Jackson reasoned, was analogous to Microsoft's argument that "that Windows and Internet Explorer represent a single 'integrated product,' and that the relevant market is a unitary market of 'platforms for software applications."'301 Judge Jackson emphasized that, in Jefferson Parish, the Supreme Court concluded "that the "character of the demand' for the constituent components, not their functional relationship, determined whether separate 'products' were actually involved" 302 and, in

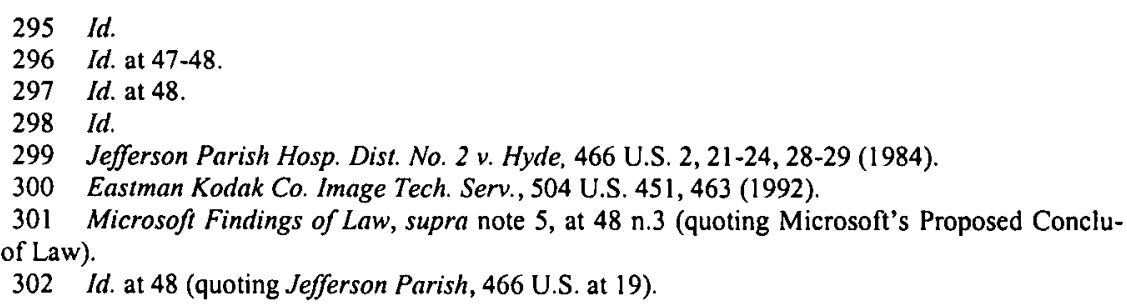


Eastman Kodak, that such a determination requires "evidence of 'actual market realities."'303

Judge Jackson was also skeptical of a business-justification defense to tying, a skepticism that he attributed to the Supreme Court's decisions in Jefferson Parish and Eastman Kodak. The Court, he observed, had considered claims that the tying arrangement had achieved productive efficiency ("scheduling, supply, performance standards, and equipment maintenance") in Jefferson Parish and had advanced "quality control, inventory management, and the prevention of free riding" in Eastman Kodak. 304 Judge Jackson emphasized that the Court did not find such "justifications sufficient if anticompetitive effects were proved." 305 That proposition, however, is a non sequitur, for a defendant need not present an affirmative defense to a tying claim if the plaintiff cannot show any anticompetitive effect. A business-justification defense that is applicable only when the elements of an unlawful tie-in have not been proven is no defense at all. This aspect of Judge Jackson's reading of Jefferson Parish and Eastman Kodak proves too much.

On the basis of his interpretation of the single-product and businessjustification aspects of Jefferson Parish and Eastman Kodak, Judge Jackson boldly concluded that a superior court was wrong on the law-that "at a minimum, the admonition of the D.C. Circuit in Microsoft II to refrain from any product design assessment as to whether the 'integration' of Windows and Internet Explorer is a 'net plus,' deferring to Microsoft's 'plausible claim' that it is of 'some advantage' to consumers, is at odds with the Supreme Court's own approach." 306 Judge Jackson said that Jefferson Parish and Eastman Kodak establish "that resolution of product and market definitional problems must depend upon proof of commercial reality, as opposed to what might appear to be reasonable." $307 \mathrm{He}$ concluded that these two Supreme Court cases obligated a court to ascertain "product and market definitions . . . by reference to evidence of consumers' perception of the nature of the products and the markets for them, rather than to abstract or metaphysical assumptions as to the configuration of the 'product' and the 'market."'308

303 Id. (quoting Eastman Kodak, 504 U.S. at 466-67 (quoting United States v. Grinnell Corp., 384 U.S. $563,572(1966)))$.

304 Id. (citing Eastman Kodak, 504 U.S. at 483).

305 Id. (citing Eastman Kodak, 504 U.S. at 483-86; Jefferson Parish, 466 U.S. at 25 n.42).

306 Id. at 49 (quoting Microsoft I/ without citation).

307 Id.

308 Id. (citing Jefferson Parish, 466 U.S. at 18; Eastman Kodak, 504 U.S. at 481-82). 


\section{The Application of Jefferson Parish and Eastman Kodak to the 1999 Findings of Fact in the Government's Microsoft Case}

Having reasoned that Microsoft II was bad law and not applicable as a general matter of antitrust law to the government's 1998 complaint that Microsoft unlawfully tied its Internet Explorer Web browser to the Windows 98 operating system, Judge Jackson proceeded to analyze the four elements of an unlawful tie-in under $\S 1$ of the Sherman Act in light of his reading of Jefferson Parish and Eastman Kodak and his 1999 findings of fact. Two of his legal findings are noteworthy. On the question of whether Internet Explorer and Windows 98 were separate products, he concluded that "the commercial reality is that consumers today perceive operating systems and browsers as separate 'products,' for which there is separate demand." 309 In Judge Jackson's estimation, this separateness of demand existed "notwithstanding the fact that the software code supplying their discrete functionalities can be commingled in virtually infinite combinations, rendering each indistinguishable from the whole in terms of files of code or any other taxonomy." 310

Second, with respect to the final element of an unlawful tie-in, Judge Jackson found that Microsoft's sale of Windows 98 was conditioned on its sale of Internet Explorer:

Microsoft refused to license Windows 98 to OEMs unless they also agreed to abstain from removing the icons for Internet Explorer from the desktop. Consumers were also effectively compelled to purchase Internet Explorer along with Windows 98 by Microsoft's decision to stop including Internet Explorer on the list of programs subject to the Add/Remove function and by its decision not to respect their selection of another browser as their default. ${ }^{311}$

The fact that Microsoft did not pursue a classic strategy of pricediscrimination through metering was of no moment to Judge Jackson. He wrote: "The fact that Microsoft ostensibly priced Internet Explorer at zero does not detract from the conclusion that consumers were forced to pay, one way or another, for the browser along with Windows." 312 Judge Jackson stated that "the purpose of the Supreme Court's 'forcing' inquiry is to expose

309 Id. at 49 (citing Microsoft Findings of Fact, supra note 183, 9 T1 149-54, 162-63, 187-91).

310 Id.

311 Id. at 50 (citing Microsoft Findings of Fact, supra note 183, १ๆ 213, 170-72).

312 Id. at 50. "Despite Microsoft's assertion that the Intermet Explorer technologies are not 'purchased' since they are included in a single royalty price paid by OEMs for Windows 98 , it is nevertheless clear that licensees, including consumers, are forced to take, and pay for, the entire package of software and that any value to be ascribed to Internet Explorer is built into this single price." Id. (citations omitted). 
those product bundles that raise the cost or difficulty of doing business for would-be competitors to prohibitively high levels, thereby depriving consumers of the opportunity to evaluate a competing product on its relative merits." 313

Judge Jackson found that Windows 98 and Internet Explorer were separate products because, under Jefferson Parish's "character of demand" analysis, Web browsers and operating systems are "distinguishable in the eyes of buyers." ${ }^{14} \mathrm{He}$ elaborated:

Consumers often base their choice of which browser should reside on their operating system on their individual demand for the specific functionalities or characteristics of a particular browser, separate and apart from the functionalities afforded by the operating system itself. Moreover, the behavior of other, lesser software vendors confirms that it is certainly efficient to provide an operating system and a browser separately, or at least in separable form. Microsoft is the only firm to refuse to license its operating system without a browser. ${ }^{315}$

Judge Jackson concluded that "Microsoft's decision to offer only the bundled-'integrated'-version of Windows and Internet Explorer derived not from technical necessity or business efficiencies; rather, it was the result of a deliberate and purposeful choice to quell incipient competition before it reached truly minatory proportions." 316

Judge Jackson acknowledged the D.C. Circuit's "admonition . . . in Microsoft II of the perils associated with a rigid application of the traditional 'separate products' test to computer software design." 317 Yet, in the next several sentences of his opinion, Judge Jackson turned that admonition into a denunciation of the D.C. Circuit's approach in Microsoft II:

Given the virtually infinite malleability of software code, software upgrades and new application features, such as Web browsers, could virtually always be configured so as to be capable of separate and subsequent installation by an immediate licensee or end user. A court mechanically applying a strict "separate demand" test could improvidently wind up condemning "integrations" that represent genuine improvements to software that are benign from the standpoint of consumer welfare and a competitive market. Clearly, this is not a desirable outcome. Similar concerns have motivated

313 Id

314 Id. (citations omitted).

315 Id. at 50-51 (citations omitted).

316 Id. at 51.

317 Id. 
other courts, as well as the D.C. Circuit, to resist a strict application of the "separate products" tests to similar questions of "technological tying." 318

Judge Jackson stated that he was "confident that [his] conclusion, limited by the unique circumstances of this case, [was] consistent with the Supreme Court's teaching to date," and he emphasized that he was "not at liberty to extrapolate a new rule governing the tying of software products." 319

Judge Jackson reinforced his conclusion by citing approvingly, though as dictum, the theory of partial substitutes contained in Professor Lessig's amicus brief and emphasizing that "the true source of the threat posed to the competitive process by Microsoft's bundling decisions stems from the fact that a competitor to the tied product bore the potential, but had not yet matured sufficiently, to open up the tying product market to competition." 320 Judge Jackson implied that software integration was special in this respect, but in a way that justified greater judicial intervention, not less. ${ }^{321}$ Quoting the 1996 and 1999 supplements to the Areeda treatise, Judge Jackson reasoned that "[a] company able to leverage its substantial power in the tying product market in order to force consumers to accept a tie of partial substitutes is thus able to spread inefficiency from one market to the next ... [and] thereby 'sabotage a nascent technology that might compete with the tying product but for its foreclosure from the market." "'322

\section{E. The Deficiency of Judge Jackson's Rule}

Judge Jackson's product integration rule is deficient for the reasons that motivated my approach in Part IV and the D.C. Circuit's product integration rule in Microsoft II. Judge Jackson's rule also fails to capture the subtlety even of Professor Lessig's rule, which itself is incomplete for the reasons that I explained in Part VII.

I do not speculate on what, in the event that Judge Jackson's decision were reversed and remanded on the product integration question, a court would subsequently conclude on the basis of the factual record that was compiled in the Microsoft trial. Nonetheless, it is possible to conclude that Judge Jackson's product integration rule is flawed on legal and economic

318 Id. (citing Foremost Pro Color, Inc. v. Eastman Kodak Co., 703 F.2d 534, 542-43 (9th Cir. 1983); Response of Carolina, Inc. v. Leasco Response, Inc., 537 F.2d 1307, 1330 (5th Cir. 1976); Telex Corp. v. Int'l Bus. Machs. Corp., 367 F. Supp. 258, 347 (N.D. Okla. 1973)).

319 Id

320 Id. at 51 n.6 (citing 10 AREEDA, ElHAUGE \& HOVENKAMP, supra note 113, ๆ 1747).

321 Id. ("Under these conditions, the anticompetitive harm from a software bundle is much more substantial and pernicious than the typical tie.").

322 Id. at 51 n.6 (quoting 10 AREeda, ElHAUge \& HovenKaMP, supra note 113, ๆ 1747 ; AREEDA \& HOVENKAMP 1999 SUPPLEMENT, supra note 114, ๆ 1746.1d). 
grounds, and that the judge failed to ensure that the record in the Microsoft case contained all of the economic evidence that would be necessary for the court to make an informed conclusion of law under a product integration rule that was properly tailored to the technological dynamism of the software industry. It is disconcerting in this regard to read, in a Washington Post interview given the day that Judge Jackson issued his final judgment ordering the divestiture of Microsoft, that the judge considered himself unable to evaluate the legal significance of the economic evidence adduced at trial: "It's important you understand what my function is here . . . I am not an economist. I do not have the resources of economic research or any significant ability to be able to craft a remedy of my own devising." 323

Much of Judge Jackson's decision on tying, particularly his reference to Professor Lessig's theory of partial substitutes, suggests that the judge was doing something more than a straightforward application of Eastman Kodak and Jefferson Parish. He seemed to consider several but not all of the four additional questions that I propose in Part IV for analyzing the lawfulness of product integration in technologically dynamic markets.

First, Judge Jackson clearly regarded software for personal computers to be a technologically dynamic market, a fact that caused him to comment in dictum about Professor Lessig's theory of preservation of monopoly over the tying product by virtue of partial substitutes. Thus, Judge Jackson could be said to have answered affirmatively the first question of my proposed rule.

With respect to the second question of my proposed rule, Judge Jackson did not address whether it is plausible that consumers will benefit from subadditive costs or superadditive demand resulting from product integration. His discussion of the scope and extent of consumer-welfare benefits from Microsoft's integration of Windows and Internet Explorer was grudging and incomplete. 324 Because his finding of fact contained no citations to the evidence introduced at trial on this subject (or for that matter, on any other subject), it is unclear how the judge reached his conclusion that only negligible consumer benefits flowed from Microsoft's product integration; it is also unclear why contradictory evidence of consumer benefits introduced at trial did not warrant the judge's comment. Given his exiguous discussion of the consumer benefits of Microsoft's software integration, Judge Jackson certainly did not present his discussion within the formal economic structure of subadditive costs and superadditive demand.

323 James V. Grimaldi, Reluctant Ruling for Judge: Jackson Says He Would Still Prefer Out-ofCourt Settlement, WASH. POST, June 8, 2000, at Al (quoting Judge Thomas Penfield Jackson).

324 Microsoft Findings of Law, supra note 5, I 186, I 193; see also Lessig Amicus Brief, supra note 4 , at 16 . 
Judge Jackson did not address in detail the topic of the third question in my proposed test. Clearly, he regarded it as probable that Microsoft's product integration would preserve a monopoly over the tying product by substantially reducing competition from the tied product. That much can be inferred from Judge Jackson's citation to Professor Lessig's theory of partial substitutes. But an enthusiastic citation to a scholar's theory (which itself is subject to the multiple ambiguities detailed above in Part VII) is not tantamount to a rigorous analysis of the economic facts necessary to apply that theory in practice.

Fourth, and finally, Judge Jackson never undertook a Williamsonian analysis of the countervailing consumer-welfare benefits and harms of product integration. To do so would have required, first, that the judge take seriously the possibility that consumer benefits of some nontrivial magnitude flow from Microsoft's software integration and, second, that he receive and evaluate the economic facts that would permit quantification of that tradeoff. Judge Jackson did neither.

\section{Conclusion}

The landmark Microsoft case presents the question of how antitrust doctrine on tying arrangements will treat the integration of software products. Given the importance of this question to the development of the New Economy, the Supreme Court will need to address this question and, in so doing, clarify the applicability, if any, of Eastman Kodak and Jefferson Parish as a product integration rule for software.

In anticipation of the Court's revisiting of the law of tying arrangements, I have proposed in this Article an antitrust rule for judging the lawfulness of software integration under $\S 1$ of the Sherman Act. My rule adds four questions to the elements that are currently contained in tying doctrine after Eastman Kodak and Jefferson Parish:

1. Is the market technologically mature or technologically dynamic?

2. Is it plausible that consumers will benefit from subadditive costs or superadditive demand resulting from product integration?

3. Is it probable that integration will preserve a monopoly over the tying product by substantially reducing competition from the tied product?

4. Will the reduction, if any, in competition cause consumer welfare losses that exceed the consumer welfare gains from subadditive costs or superadditive demand? 
An Antitrust Rule for Software Integration

The purpose of these additional elements for liability is to produce an antitrust rule that recognizes that the consumer-welfare effects of product integration in technologically mature markets differ markedly from those in technologically dynamic markets. As long as the law of tying arrangements fails to make that distinction, it is as likely to harm consumer welfare in the New Economy as to enhance it. 
